\title{
Distribution of Chemical
}

Elements in the Salt Wash

Member of the Morrison

Formation, Jo Dandy Area

Montrose County, Colorado

GEOLOGICAL SURVEY BULLETIN $1084-E$

This report concerns work done on behalf of the U.S. Atomic Energy Commission and is published with the permission of the Commission

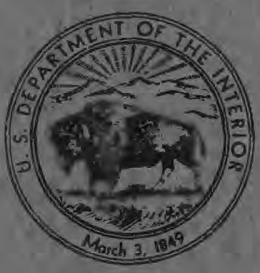


$\operatorname{lin} 8$

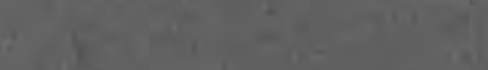

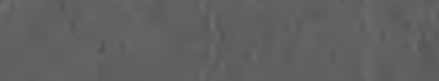

10. 18 and

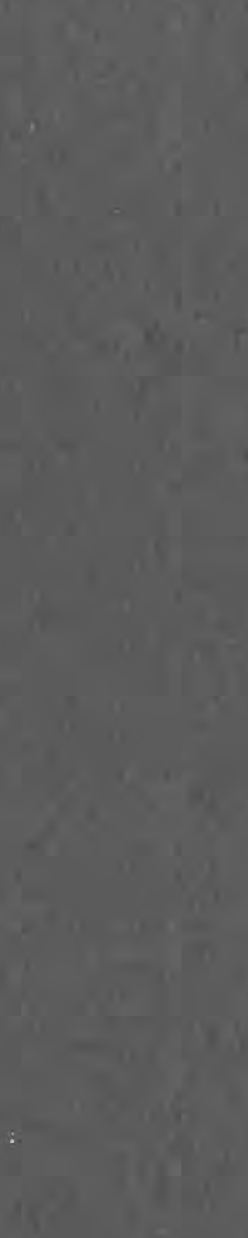

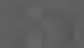

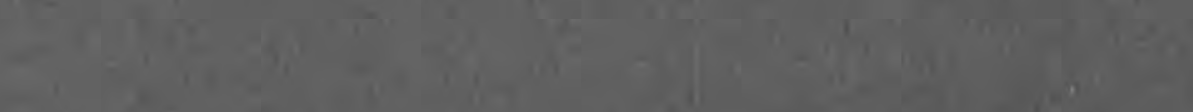

$\lim ^{2}+x^{2}+2$

(1)

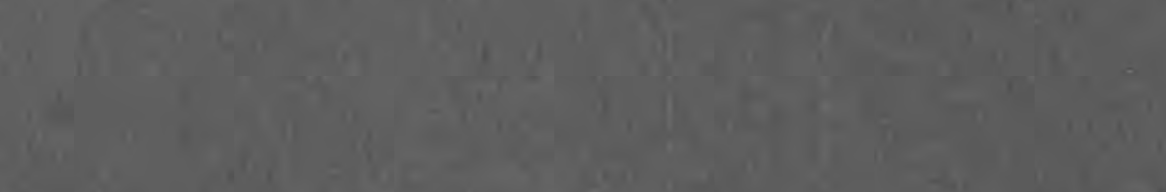

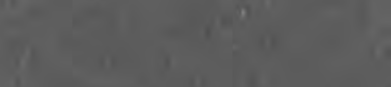

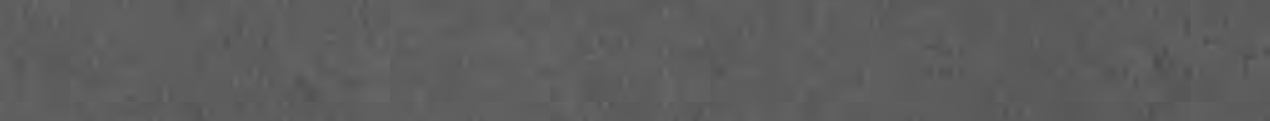

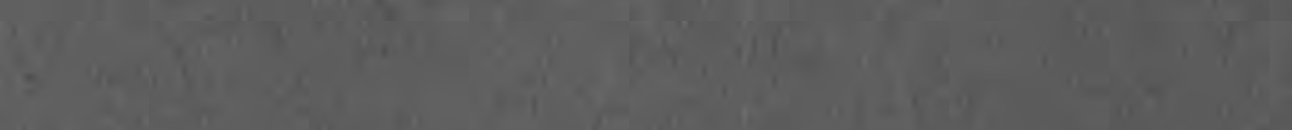

a

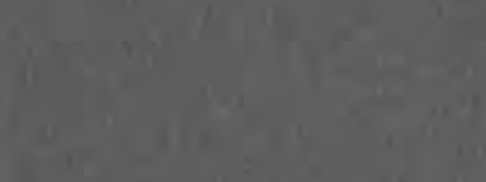

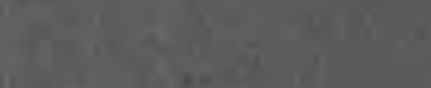

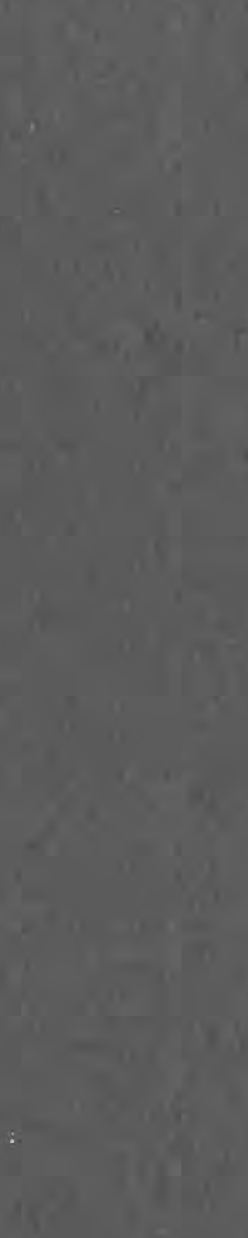

iv

$\sum_{1=1}$

(1)

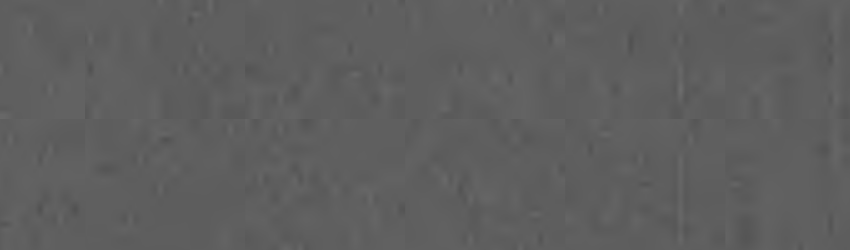

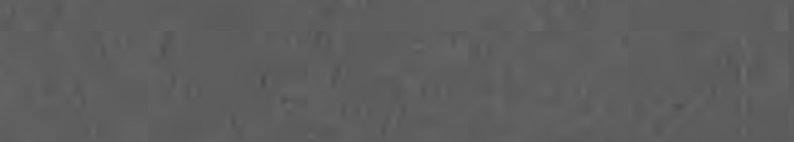

$$
\begin{aligned}
& \text { (.) } \\
& n_{1}=T_{n}
\end{aligned}
$$$$
1^{2}
$$$$
+1
$$

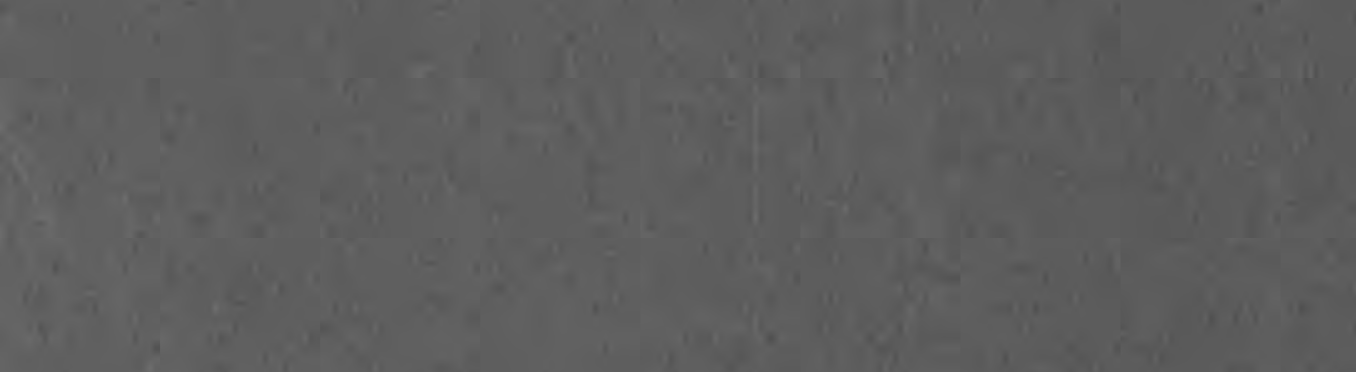
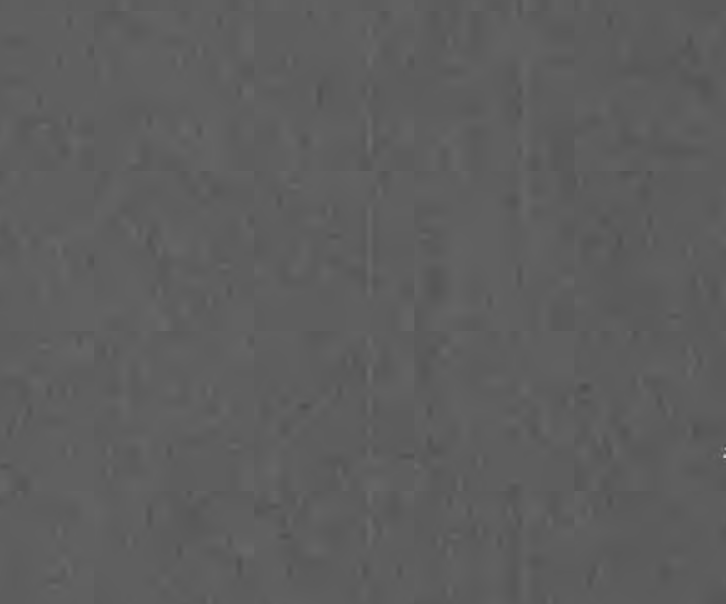


\section{Distribution of Chemical}

\section{Elements in the Salt Wash}

Member of the Morrison

Formation, Jo Dandy Area

Montrose County, Colorado

By WILLIAM L. NEWMAN and DONALD P. ELSTON

CONTRIBUTIONS TO GEOCHEMISTRY

GE OLOG I CALSU R VEY B U L LE T I N 1084-E

This report concerns work done on behalf of the U.S. Atomic Energy Commission and is published with the permission of the Commission

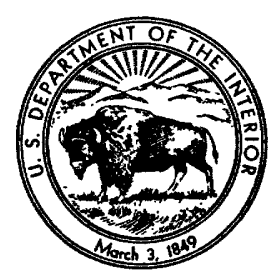




\section{UNITED STATES DEPARTMENT OF THE INTERIOR}

FRED A. SEATON, Secretary

\section{GEOLOGICAL SURVEY}

Thomas B. Nolan, Director 


\section{CONTENTS}

\begin{tabular}{|c|c|}
\hline & Page \\
\hline & 117 \\
\hline $\cos ^{-1}$ & 118 \\
\hline gic setting & 119 \\
\hline mple collection & 123 \\
\hline atistical treatment of spectrographic data & 126 \\
\hline riations in compositions of host rocks & 128 \\
\hline Silicon & 128 \\
\hline Aluminum & 128 \\
\hline ( & 128 \\
\hline esium & 129 \\
\hline ( & 129 \\
\hline and sodium & 129 \\
\hline and zirconium & 129 \\
\hline ( & 130 \\
\hline strontium & 130 \\
\hline and boron & 131 \\
\hline (2n-1 & 131 \\
\hline 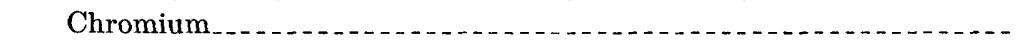 & 131 \\
\hline um, ytterbium, gallium, scandium, and lanthanum & 13 \\
\hline Nickel and cobalt & 13 \\
\hline Copper & 133 \\
\hline Lead, molybdenum, and silver & 133 \\
\hline $1{ }^{-1}$ & 134 \\
\hline ranium, & 134 \\
\hline hemical composition of host rocks & 134 \\
\hline $\begin{array}{c}-1 \\
-1\end{array}$ & 13 \\
\hline ion of samples..................... & \\
\hline & \\
\hline
\end{tabular}

\section{ILLUSTRATIONS}

Figure 19. Index map of part of the Colorado Plateau showing location of Jo Dandy area

20. Generalized geologic map of part of the Jo Dandy area....... 21. Schematic stratigraphic correlation diagrams of part of the Salt Wash member of the Morrison formation, Jo

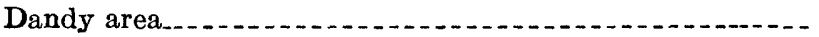




\section{TABLES}

TABLE 1. Method of reporting semiquantitative spectrographic analy-

Page ses _

2. Statistically determined average chemical compositions of mudstone and sandstone of the Salt Wash member of the Morrison formation, Jo Dandy area, Montrose County,

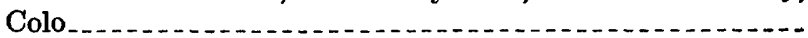
3. Semiquantitative spectrographic and radiometric analyses of rocks of the Jo Dandy area, Montrose County, Colo....... 


\title{
CONTRIBUTIONS TO GEOCHEMISTRY
}

\section{DISTRIBUTION OF GHEMICAL ELEMENTS IN THE SALT WASH MEMBER OF THE MORRISON FORMATION, JO DANDY AREA, MONTROSE COUNTY GOLORADO}

\author{
By William L. Newman and Donald P. Elston
}

\begin{abstract}
A study of the distribution of the chemical elements in samples from the Salt Wash member of the Morrison formation of Late Jurassic age in the Jo Dandy area, Montrose County, Colo., was made to determine average chemical compositions of mudstone and sandstone and to determine the magnitude of variations in the concentrations of elements within similar rock types. Analytical data were obtained by semiquantitative spectrographic and radiometric methods.

Results of the study show that variations in concentrations of about 20 elements commonly detected by semiquantitative spectrographic analyses of sedimentary rocks are small for a specific rock type; therefore, considerable confidence may be placed upon the average chemical composition derived from the sample populations. In addition, there appears to be no significant relation between the chemical composition of mudstone or sandstone and the distance from known uranium-vanadium ore or mineralized rock.

Mudstone generally contains greater concentrations of the elements studied than sandstone. The chemical composition of red mudstone is similar to the chemical composition of green mudstone except that red mudstone was found to contain almost twice as much calcium as green mudstone in the Jo Dandy area.

Samples of unoxidized sandstone from the Jo Dandy area contain about twice as much calcium, three times as much strontium, but only about one-half as much zirconium as oxidized sandstone; except for these elements the chemical compositions of both categories of sandstone are similar. Samples of sandstone of the Salt Wash member in the Jo Dandy area contain more potassium, magnesium, vanadium, and nickel than "average" sandstone of the Salt Wash member.

The distribution of bismuth in rocks of the Jo Dandy area suggests that bismuth and perhaps part of the potassium and magnesium found in rocks of the Salt Wash member were derived either from solutions which ascended from the underlying salt- and gypsum-bearing Paradox member of the Hermosa formation or were contained in gypsiferous material of the Paradox member that was incorporated with rocks of the Salt Wash during sedimentation.
\end{abstract}




\section{INTRODUCTION}

In 1954, a chemical study was made of the Salt Wash member of the Morrison formation of Late Jurassic age in the Jo Dandy area, Montrose County, Colo. (fig. 19). This area is one of the important uranium-vanadium producing areas of the Colorado Plateau, and within this area sandstone strata in the upper part of the Salt Wash member contain the principal ore deposits. The chemical study was made to investigate the distribution of elements in the host rocks with emphasis on the pattern of variation as related to the position

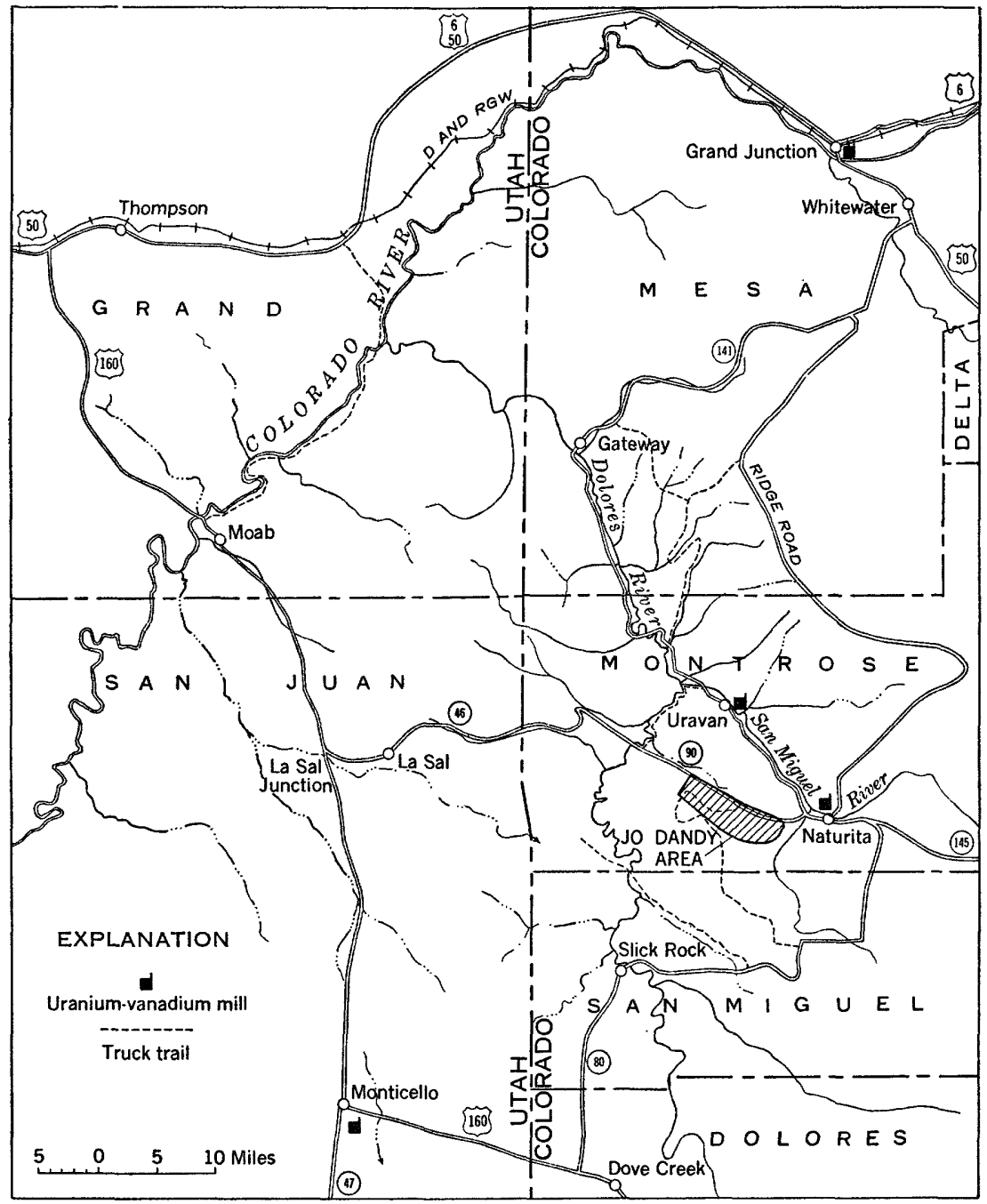

Figuri 19.-Index map of part of the Colorado Plateau showing location of the Jo Dandy area, Montrose County, Colo. 
of known ore bodies, and to determine average concentrations of some of the elements in the major rock types.

The study is based upon the detailed knowledge of the area gained as a result of surface mapping by Cater (1955), and by surface and mine mapping and diamond-drill exploration conducted by the U.S. Geological Survey during 1949-56 on behalf of the Division of Raw Materials of the U.S. Atomic Energy Commission.

Samples largely taken from drill cores were analyzed for chemical constituents and equivalent uranium content in the Denver laboratories of the U.S. Geological Survey. Spectrographic analyses were done by G. W. Boyes, Jr., and radiometric analyses were done by J. Patton.

\section{GEOLOGIC SETTING}

The Jo Dandy area is near the southeast end of Paradox Valley, Montrose County, Colo. (fig. 20). Paradox Valley is a narrow, elongate northwestward-trending valley about 20 miles long and 3 to 4 miles wide that has formed as a result of subsidence and removal of strata along the crest or axis of a salt anticline. The core of the anticline consists of plastically deformed salt, gypsum, black shale, sandstone, and limestone of the Paradox member of the Hermosa formation of Middle Pennsylvania age. Intrusion of the plastic material of the Paradox member began sometime during deposition of the Cutler formation of Permian age, probably in response to weak compressive forces.

This material ruptured the overlying beds and broke through to the surface at the end of deposition of the Cutler formation (Cater, 1955). From then until Late Jurassic time there was a general, although locally imperfect, isostatic balance between sedimentation on the flanks of the salt structure and upwelling and removal of plastic and soluble materials of the Paradox member along the axis of the structure.

During Late Jurassic time the Morrison and younger formations were deposited across the salt structure. Deformation, before middle Tertiary time, caused the formation of a broad anticline along the trend of the salt structure; salt flowage was renewed, and normal faults developed along the crest of the fold probably during relaxation of compressive stresses (Cater, 1955). The folding was followed by base leveling and later by regional uplift in middleTertiary time, and the crest of the structure was breached by erosion. Thick wedges of strata on the flanks of the anticline settled by normal faulting as the plastic material was pressed out from under the sides and ends of the structure and as soluble material was re- 


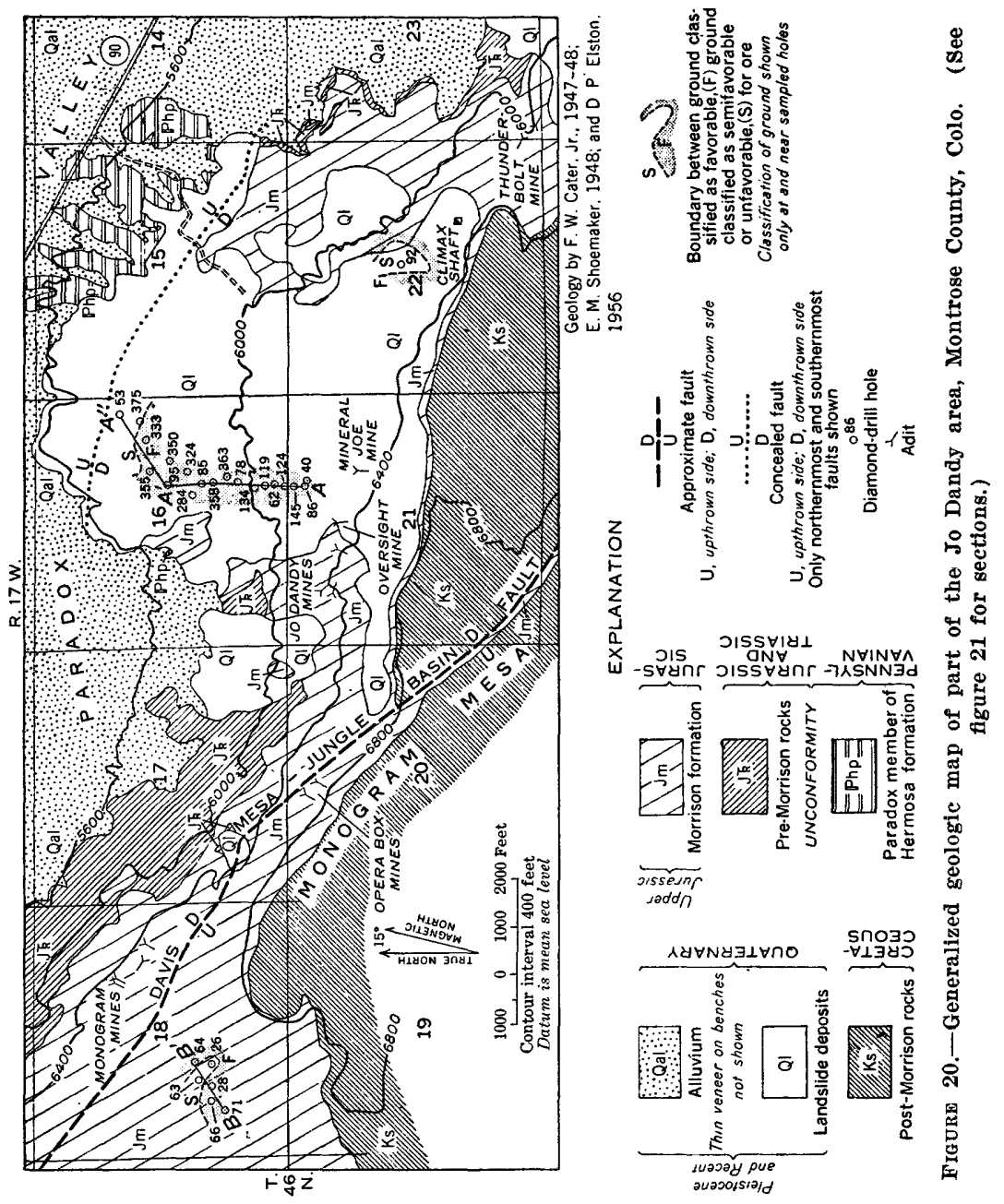


moved. The major part of the settling may have been completed prior to Quaternary time, but minor adjustments continued during parts of the Pleistocene and into Recent time. Erosion has removed much of the strata from the axial part of the anticline leaving gypsiferous masses of the Paradox member exposed in the valley floor.

Both faulted and unfaulted sedimentary strata are included in the Jo Dandy area between the floor of Paradox Valley on the northeast and the rim of Monogram Mesa on the southwest (fig. 20). In parts of secs. 15, 16, 21, and 22, T. 46 N., R. 17 W., late Paleozoic and Mesozoic strata, which originally formed part of the southwest flank of the anticline, have settled differentially with regard to adjacent Permian strata concealed beneath alluvium on the northwest, Mesozoic strata on the south and east, and gypsum of the Paradox member on the north. The differential movement of these strata is caused by foundering of competent rocks in the relatively plastic salt and gypsum core of the anticline. Rocks in this area were mapped as landslide material, and this area is called the Jo Dandy landslide by Elston, Botinelly, and Shoemaker (written communication). Strata older than the Morrison formation of Late Jurassic age pinch out from south to north under the landslide. Under the northcentral part of the landslide the Morrison formation overlies gypsiferous black mudstone, gray limestone, and gypsum of the Paradox member.

Drilling has shown that strata in the landslide area are cut by a series of normal faults; most of the fault blocks are displaced downward toward the valley, with displacements locally of more than 150 feet. In the landslide area, many of the faults, like those exposed on the valley wall to the west, generally parallel the northwest trend of the valley and have resulted from collapse of the anticlinal structure; in places however, faults related to local differential settling crosscut the northwesterly set. All faults observed in the Jo Dandy area appear to be younger than the ore deposits.

In the Jo Dandy area the Morrison formation, which contains the principal ore-bearing beds, is about 700 feet thick and is divided into two members of about equal thickness. The lower Salt Wash member consists of broad lenses of sandstone interbedded with reddish-brown and grayish-green mudstone; the upper Brushy Basin member consist of variegated, bentonitic mudstone, scattered lenses of conglomeratic sandstone, very fine grained quartzitic sandstone, and thin limestone beds.

The Salt Wash member consists of 3 to 5 prominent layers of sandstone separated by mudstone strata of varying thickness. The uppermost sandstone layer is called the ore-bearing sandstone as it contains 
all of the productive uranium deposits in the area. The ore-bearing sandstone ranges from a featheredge to about 130 feet in thickness.

Individual sandstone layers in the Salt Wash member consist of a series of lenses which range from about 5 to 60 feet in thickness and from a few hundred to a few thousand feet in length. They are commonly separated by seams of mudstone. The attitude of bedding within the lenses or composite sets (McKee and Weir, 1953, p. 383) is varied and ranges from horizontal to steeply dipping crossbeds. The individual sandstone layers near the top and base of the member crop out prominently and are laterally extensive throughout the area. The intermediate layers are less persistent and only locally do all the sandstone layers coalesce or nearly coalesce to form an almost continuous vertical cliff of sandstone.

Sandstone of the Salt Wash member is composed dominantly of quartz grains; feldspar and dark minerals are minor constituents. Mudstone, commonly pale green, is present as intergranular material, as flakes, and as thin discontinuous seams.

Mudstone strata that separate the sandstone layers of the Salt Wash member are generally reddish brown, but mudstone adjacent to and within the lower and upper sandstone layers are commonly grayish green. The thickest and most laterally persistent mudstone interval underlies the ore-bearing sandstone. It is commonly about 75 feet thick.

The distribution of green mudstone has been observed to coincide with the occurrence of mineralized sandstone in many areas; therefore, the color of mudstone adjacent to sandstone beds has been used as a criterion for the classification of ground as to favorableness for ore (Weir, 1952; McKay, 1955).

The color of sandstone is also used to classify ground as to favorableness for ore. Color is due to the presence of iron in the form of sulfides and oxides. Unoxidized sandstone classified as favorable for ore is light gray and contains scattered crystals of pyrite and marcasite. Its oxidized equivalent is generally light to dark brown. In many places oxidized sandstone has a freckled appearance due to discrete brown dots of limonite derived from oxidation of the iron sulfides. Sandstone classified as unfavorable for ore is found both above and below the present water table and ranges from light to dark gray and has a pale-red to dark-red cast. Sulfides are absent. The red color of clay of the Salt Wash is due to minute dispersed particles of iron oxide which pigment the clay minerals (Weeks, 1951, p. 12). The pigment of red sandstone is believed to be due to a pervasive coating of anhydrous ferric oxide, probably hematite.

The grain size of sandstone is another criterion for classifying ground as to favorableness for ore. Sandstone classified as favorable 
for ore generally ranges in grain size from fine to medium grained; whereas, sandstone classified as semifavorable and unfavorable for ore is commonly very fine grained and silty.

Uranium ore in the Jo Dandy area consists mainly of sandstone impregnated with oxidized and partly oxidized uranium and vanadium minerals, but some unoxidized uranium ore is present. In many places the ore minerals follow the bedding of the host sandstone in detail, but the upper and lower edges of a mineralized layer typically crosscut the larger bedding features at low angles. Within a mineralized layer high-grade concentrations of uranium and vanadium minerals occur in concretionary masses or pods commonly associated with carbonaceous material. Local high-grade concentrations also occur in sandy mudstone, pebbly carbonaceous-trash layers, and in traps produced by wedging sandstone beds. Rolls, in which ore boundaries sharply crosscut the sedimentary bedding to form C-shaped figures, have been observed in both unoxidized and oxidized ore; diffuse S-shaped rolls, confined to a single bed but crosscutting laminae of the bed, have been observed only in oxidized ore. Field observations suggest that there is little redistribution of ore minerals during oxidation of uranium-vanadium ore (D. P. Elston and Theodore Botinelly, written communication).

Individual ore deposits range from about 50 to 2,000 feet in length and from 25 to 500 feet in width. Thicknesses of ore-grade and mineralized rock are locally in excess of 30 feet, but ore layers are commonly 3 to 5 feet thick.

The geology of the Jo Dandy area, summarized above, forms the basis for the chemical study described in the following sections. Data obtained from diamond-drill exploration enabled fairly precise correlations of sandstone and mudstone strata to be made throughout the area. In addition, the drilling provided drill core for analytical work. The detailed information concerning the stratigraphy of the Salt Wash member and the position, size, and trend of ore deposits led to the selection of the Jo Dandy area as an ideal place to study the distribution of elements in host rocks of the Salt Wash member.

\section{SAMPLE COLLECTION}

Eighty-eight samples of drill core from nine diamond-drill holes were selected for analysis. One or more core samples were taken to represent each major lithologic unit penetrated in each drill hole. The samples were NX-sized cores (21/8 inches in diameter), and averaged 0.5 foot in length.

Core was taken from 7 holes that were drilled in the landslide area (figs. 20 and 21). Six of these holes are shown in section $A-A^{\prime}-A^{\prime \prime}$ (fig. 21). Two holes (62 and 78) penetrated ore in the 


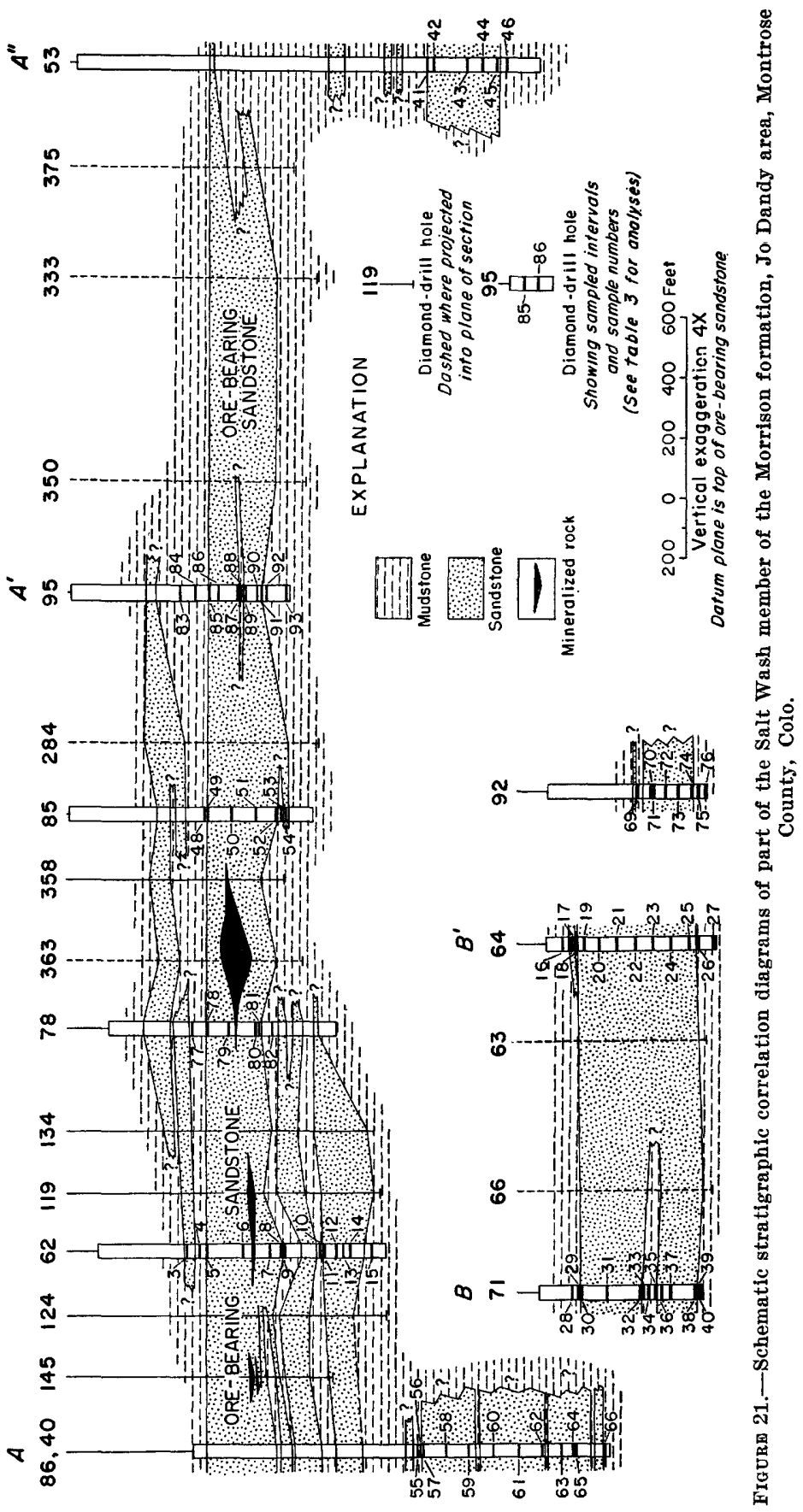


ore-bearing sandstone and 1 hole (53) penetrated mineralized rock in the Paradox member of the Hermosa formation. Of the 6 holes, 5 holes are in ground classified as favorable for ore, and 1 hole is in ground classified as unfavorable for ore. Core samples were taken from lower strata of the Salt Wash member in 2 holes (86 and 53), and core samples were taken from the upper or ore-bearing strata in the remaining 4 holes. The remaining hole (92) sampled in the landslide area (figs. 20 and 21) penetrated ground classified as semifavorable for ore, but ore-bearing ground lies about 700 feet south of this hole.

Core samples were also taken from 2 holes drilled in the vicinity of the Monogram mines, about 2 miles west of the landslide area (section $B-B^{\prime}$, holes 71 and 64 , figs. 20 and 21 ). These holes penetrated upper strata of the Salt Wash member classified as favorable for ore; however, these holes straddle a lobe of ground classified as semifavorable for ore. Ground southwest of the semifavorable lobe is classified as favorable for ore, but is mostly barren of uranium and vanadium minerals. There is an ore deposit about 350 feet northeast of section $B-B^{\prime}$.

Lithologic data from these nine drill holes were combined with surrounding drill-hole data to determine the internal stratigraphy of the Salt Wash member. Along the lines of section, lithologic logs of adjacent drill holes have been plotted to demonstrate the additional stratigraphic control, but samples were not taken from these holes.

Datum for the correlation diagrams is the top of the ore-bearing sandstone. About 30 feet of reddish-brown and grayish-green mudstone and very fine grained sandstone commonly separates the top of the ore-bearing sandstone from the basal sandstone strata of the Brushy Basin member. In places where the basal sparsely conglomeratic sandstone of the Brushy Basin member is channeled into the ore-bearing sandstone the datum is the contact of these two sandstone units.

In addition to samples of drill core, 2 samples ( 1 and 2 ) of rock gypsum of the Paradox member were collected from outcrops in Paradox Valley, and a specimen of selenite (sample 67, table 3) was taken from a fracture in the Mineral Joe mine. One of the samples of rock gypsum (sample 1, table 3) was collected from a bulldozer cut on the west side of the landslide area (fig. 20). The second sample of rock gypsum (sample 2, table 3) was collected about 3 miles west of the intersection of Colorado Highway 90 and the Monogram truck trail. The location of this sample site is not within the area shown on figure 20. (See pages 139-143 for lithologic description of samples.) 


\section{STATISTICAL TREATMENT OF SPECTROGRAPHIC DATA}

Samples of rock selected for study were analyzed for chemical elements by the rapid and relatively inexpensive semiquantitative spectrographic method. In this procedure a weighed amount of the sample mixture is burned in a controlled $d-c$ arc and the spectrum recorded on a photographic plate. Selected lines on the resulting plate are visually compared with those of standard spectra prepared in a manner similar to that for the unknowns. The standard spectra were prepared from mixtures of materials containing 68 elements in the following concentrations (expressed in percent) : 10, 4.6, 2.2, 1.0, 0.46 , etc. (see table 1 ). These values were chosen so that the concentrations of the elements decrease from 10 percent to about 0.0001 percent by a factor of the reciprocal of the cube root of 10 . This factor provides a geometric concentration series having three members for each order of magnitude and which is consistent with the relation between the blackness of the spectral line and the amount of an element present. By means of a comparator showing enlarged adjacent images of the sample spectra and the standard spectra, visual estimates are made of concentrations of the elements in the sample which are then reported as being between two standards in the following manner: $X$ indicating the middle portion (5-2 percent) of an order of magnitude; $\mathrm{X}+$ the higher portion (10-5 percent); and $\mathrm{X}$ - the lower portion (2-1 percent).

TABLE 1.-Method of reporting semiquantitative spectrographic analyses

\begin{tabular}{|c|c|c|c|}
\hline \multirow{2}{*}{ Concentrations reported by laboratory } & \multicolumn{2}{|c|}{ Theoretical range (percent) } & \multirow{2}{*}{$\begin{array}{l}\text { Theoretical mid- } \\
\text { point (percent) }\end{array}$} \\
\hline & From- & To- & \\
\hline 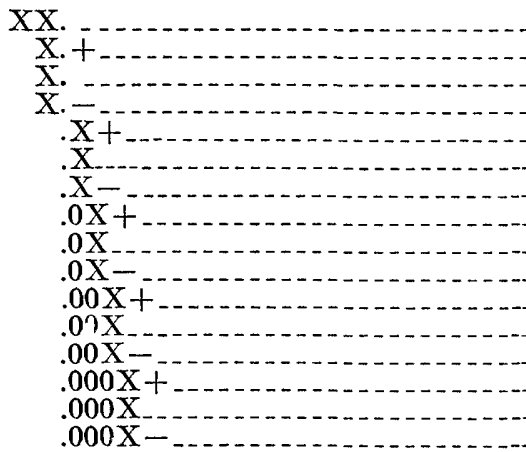 & $\begin{array}{l}\text { 10. } 0 \\
4.6 \\
2.2 \\
1.0 \\
.46 \\
.22 \\
.10 \\
.046 \\
.022 \\
.010 \\
.0046 \\
.0022 \\
.0010 \\
.00046 \\
.00022 \\
.00010\end{array}$ & $\begin{aligned} 100.0 \\
10.0 \\
4.6 \\
2.2 \\
1.0 \\
.46 \\
.22 \\
.10 \\
.046 \\
.022 \\
.010 \\
.0046 \\
.0022 \\
.0010 \\
.00046 \\
.00022\end{aligned}$ & $\begin{array}{l}6.8 \\
3.2 \\
1.5 \\
.68 \\
.32 \\
.15 \\
.068 \\
.032 \\
.015 \\
.0068 \\
.0032 \\
.0015 \\
.00068 \\
.00032 \\
.00015\end{array}$ \\
\hline
\end{tabular}

Symbols used in table 3:

Tr., trace, near threshold of spectrographic method (below limit of detectability).

0 , looked for but not detected.

...., not looked for. 
The above method of reporting is used because the inherent limitations of this particular method of spectrographic analysis make the precision of the determinations less than the precision attained in preparing the standards. Major sources of error are chemical and physical differences between the samples and the standards, the omission of complete quantitative procedures for sample preparation and plate calibration, and lack of duplicate determinations.

The range of sensitivity differs considerably for different elements; for example, the lower limit approaches 0.0001 percent for zinc, and 0.2 percent for phosphorus. Concentrations above 5 percent cannot be determined accurately by this method.

For purposes of comparing the chemical composition of one sample with that of another sample, the data provided by the semiquantitative spectrographic method are not satisfactory unless the differences in concentration for a given element are quite large, as for example from $0.00 \mathrm{X}$ percent in one sample as compared to $0 . \mathrm{X}$ percent in another. The data are, on the other hand, sufficient to calculate the average concentration of a given element in a specified rock type providing many samples are used. The confidence that can be placed upon such a calculated average is a function of the number of samples.

In calculating the average concentration of an element in a specific rock type, use is made of the nature of the frequency distribution of the element in the sample suite. The frequency distribution of most elements that lie above the limit of detectability in sandstone has been found by chi square tests to be approximately lognormal, and the statistical theory for normal or Gaussian distribution may be applied to the spectrographic data with the least bias after log transformation. Ahrens (1954) similarly found that the concentrations of many elements have lognormal distributions in a given rock type.

The simplest and generally most useful measure of central tendency that may be computed from the spectrographic analyses is the arithmetic mean of the logs of the concentration, the antilog of which is the geometric mean. The geometric mean is not unduly affected by one or several exceedingly high or exceedingly low values.

Geometric means representing the estimated chemical composition of various types of sedimentary rocks in the Jo Dandy area were calculated from spectrographic data by assuming a midpoint for each logarithmic interval as shown in table 1. For each geometric mean shown the theoretical range is given based upon the number of samples used, for 99 percent confidence. 


\section{VARIATIONS IN COMPOSITIONS OF HOST ROCKS}

Analytical data were used to determine significant variations in composition of the two major rock types, sandstone and mudstone, and also to determine variations within each rock type. Variations in concentration of each element were determined by plotting chemical data in their proper sample interval within the graphic log of each drill hole. Graphic logs of each hole were then plotted to form stratigraphic correlation diagrams (fig. 21).

\section{SILICON}

In all samples of sandstone and mudstone the silicon content was greater than 10 percent and is therefore too high to be estimated by semiquantitative spectrographic methods. In samples of gypsum the silicon content ranged from $0.0 \mathrm{X}$ percent in a crystal of selenite to $0 . \mathrm{X}+$ percent in a sample of rock gypsum from the Paradox member. (See table 1 for explanation of the method used to report spectrographic analyses.) The amount of silicon over $0.0 \mathrm{X}$ percent may thus be taken as a rough estimate of the amount of extraneous material, such as sandstone and mudstone, that is incorporated with the evaporite of the Paradox member.

\section{ALUMINUM}

The concentrations of aluminum in mudstone range from X.to $\mathrm{X} .+$ percent, but only 3 samples of mudstone out of 32 contained less than $\mathrm{X}$. percent. The aluminum content of mudstone in the Jo Dandy area is, therefore, quite constant as determined by the spectrographic method. Concentrations of aluminum in sandstone range from $0 . \mathrm{X}$ - to $\mathrm{X}$.+ percent, but only one sample of sandstone contained more than X. percent. Sandstone samples that contain the higher concentrations of aluminum also contain greater amounts of clay filling interstices, or occurring as films, seams, or pellets. The amount of aluminum in sandstone, therefore, is roughly proportional to the amount of clay contained in the sandstone.

\section{IRON}

The concentrations of iron in mudstone range from $0 . \mathrm{X}+$ to $\mathrm{X}$. percent. But only two samples of mudstone contained as much as $\mathrm{X}$. percent iron; therefore, the iron content in mudstone is quite consistent. Sandstone contains concentrations of iron that range from $0 . X-$ to $X$. percent. One sample of sandstone from hole 71 (sample 37, table 3) contains disseminated crystals of pyrite. The iron content of this one sample is correspondingly high and contains X.- percent iron. Correlative strata of sandstone show very little 
variation in iron content, however, nor a consistent pattern of concentration with depth.

\section{MAGNESIUM}

The range in concentrations of magnesium in mudstone is rather a narrow one, extending from $0 . \mathrm{X}+$ to $\mathrm{X}$. percent, whereas the range in concentrations in sandstone is quite wide, extending from $0.0 \mathrm{X}$ to $\mathrm{X}$. percent. Variations in correlative strata are not systematic, however. In some holes (62, 71, 53, and 92, fig. 20), the magnesium content in sandstone increases with depth, whereas in other holes $(78,85,95$, and 86, fig. 20$)$ the concentration of magnesium decreases with depth.

\section{CALCIUM}

The calcium content of the Salt Wash member does not vary systematically within correlative lithologic units, nor are there systematic variations in calcium content with depth. The concentrations of calcium in mudstone range from $0 . \mathrm{X}$ - to $\mathrm{X}$. percent, whereas the calcium content in sandstone ranges from $0.0 \mathrm{X}+$ to $\mathrm{X} .+$ percent. There appears to be no observable relation between the distribution of calcium in sandstone and the distribution of known ore bodies, but lateral and vertical sample intervals are too wide spaced to show variations which may occur in and close to ore.

\section{POTASSIUM AND SODIUM}

The concentrations of potassium in mudstone range from X.- to $X$. percent, a narrow spread of values. Concentrations of potassium in sandstone show a greater range of values extending from less than trace amounts (about $0 . \mathrm{X}$ - percent) to X.- percent. The range in concentrations of sodium in mudstone is from $0.0 \mathrm{X}+$ to $0 . X$ percent, but only one sample of mudstone contained less than 0.X- percent. Concentrations of sodium in sandstone range from trace amounts (about $0.0 \mathrm{X}$ - percent) to $0 . \mathrm{X}$ percent, but only one sample contained more than $0 . X$ - percent.

The concentrations of potassium throughout the sandstone beds are very similar, both laterally and vertically. This is equally true for the concentrations of sodium. Sandstone in hole 64 (section $B-B^{\prime}$, fig. 21), however, contains somewhat less potassium and sodium than commonly found in sandstone of the Salt Wash member in the Jo Dandy area.

\section{TITANIUM AND ZIRCONIUM}

Concentrations of titanium in mudstone range from $0.0 \mathrm{X}$ to $0 . \mathrm{X}$ percent, and in sandstone the range is from $0.00 \mathrm{X}+$ to $0 . \mathrm{X}-$ percent. 503314-59-3 
Zirconium in mudstone ranges in concentration from $0.00 \mathrm{X}$ to $0.0 \mathrm{X}-$ percent and in sandstone from $0.00 \mathrm{X}$ - to $0.0 \mathrm{X}$ - percent. Although the total amount of titanium in the host rocks is somewhat greater than the total amount of zirconium, the two elements show geochemical affinites. Both elements are concentrated in the fine-grained sediments such as mudstone and claystone, and the concentration of one element varies directly with the concentration of the other.

\section{MANGANESE}

Ranges of concentration of manganese in both mudstone and sandstone are very nearly alike; concentrations of manganese in mudstone range from $0.00 \mathrm{X}$ to $0.0 \mathrm{X}+$ percent, and the concentrations in sandstone range from $0.00 \mathrm{X}$ to $0.0 \mathrm{X}$ percent. Variations in manganese content throughout sandstone strata are of small magnitude, although there are indications that manganese tends to be slightly concentrated at the top and bottom of sandstone lenses. Manganese appears to vary directly in concentration with that of calcium. A high positive correlation of calcium with manganese was also observed in a regional study of the distribution of elements in sandstone of the Salt Wash member. Manganese may be contained largely in solid solution in calcite.

\section{BARIUM AND STRONTIUM}

The concentrations of barium in mudstone range from $0.00 \mathrm{X}+$ to $0.0 \mathrm{X}$ percent, whereas concentrations in sandstone range from $0.00 \mathrm{X}+$ to $0 . \mathrm{X}$ - percent. However, only one sample of sandstone contained more than $0.0 \mathrm{X}+$ percent barium, and that sample (59, hole 86) also contained abundant tiny fractures filled with gypsum and probably barite. The average barium content in mudstone and in sandstone is very similar. Sandstone enclosing an ore body in hole 62 (samples 6 and 7 ) contains less than the average amounts of barium, and the sample of sandstone nearest ore-grade material in hole 78 (sample 79) also contains less than average amounts of barium. In general, the uppermost and lowermost parts of the ore-bearing sandstone appear to contain slightly more barium than the central parts. The variations in concentration are so slight, however, that they are of questionable significance.

Concentrations of strontium in mudstone show only a narrow spread of values that range from $0.00 \mathrm{X}+$ to $0.0 \mathrm{X}$ percent, and only one sample contained more than $0.0 \mathrm{X}$ - percent strontium. Concentrations of strontium in sandstone, however, show a wide spread of values that range from $0.00 \mathrm{X}$ - to $0.0 \mathrm{X}+$ percent, but concentrations of strontium do not show a systematic variation except with 
the oxidation state of sandstone as described in a subsequent section of the report. Barium and strontium appear to be geochemically related, for, with few exceptions, the concentrations of each element vary coincidentally.

\section{BERYLLIUM AND BORON}

Except for one sample, beryllium was found in detectable quantities only in mudstone. The one exception is a sample of very fine to fine grained sandstone (hole 64, sample 17) taken from a thin lens above the ore-bearing sandstone. This sample contained $0.000 \mathrm{X}$ percent beryllium. Most samples of mudstone contained from trace to $0.000 \mathrm{X}$ - percent beryllium, although in a few samples of mudstone beryllium was not detected.

Boron likewise tends to become concentrated in the finer grained sediments. Concentrations in mudstone range from $0.00 \mathrm{X}-$ to $0.0 \mathrm{X}$ percent, whereas concentrations in sandstone range from below trace amounts (about $0.000 \mathrm{X}+$ percent) to $0.00 \mathrm{X}$ percent. No systematic variations in the concentrations of these two elements are indicated by the data.

\section{VANADIUM}

Concentrations of vanadian in mudstone range from $0.00 \mathrm{X}$ to $0.0 \mathrm{X}$ percent; whereas concentrations in sandstone range from trace amounts (about $0.000 \mathrm{X}+$ percent) to $0.0 \mathrm{X}$ - percent. Concentrations of vanadium are remarkably constant within correlative lithologic units but vanadium may be slightly more concentrated in sandstones in zones which correlate laterally with mineralized zones. This relationship is particularly apparent in hole 64 in which somewhat higher concentrations of vanadium occur near the base of the orebearing sandstone layer. In drill hole 26 a trace of carnotite coating fracture surfaces was found at the same stratigraphic position as the high vanadium values found in hole 64 . The concentration of vanadium in sandstone either above or below known ore bodies show no persistent relations to the ore bodies, however.

\section{CHROMIUM}

Concentrations of chromium in mudstone range from $0.00 \mathrm{X}$ - to $0.00 \mathrm{X}+$ percent, and in sandstone the concentrations range from $0.000 \mathrm{X}$ to $0.00 \mathrm{X}$ percent. Thus it is apparent that chromium is concentrated in the fine-grained sediments. Mudstone at the base of the ore-bearing sandstone consistently contains $0.00 \mathrm{X}$ percent chromium regardless of color (red or green), as do the thin beds of mudstone within the ore-bearing sandstone. Mudstone at the top of the orebearing sandstone may contain slightly less chromium than basal 
mudstone, whereas the basal sandstone Iayer may contain slightly more chromium than the upper sandstone Iayer. The distribution of chromium does not appear to be related to the distribution of known ore bodies, however.

\section{YTTRIUM, YTTERBIUM, GALLIUM, SCANDIUM, AND LANTHANUM}

These elements are closely related in their mode of occurrence; each tends to be concentrated in the finer grained rocks. Yttrium commonly occurs in concentrations above trace amounts only in mudstone which contains from $0.00 \mathrm{X}$ - to $0.00 \mathrm{X}$ percent, but a few samples of oxidized sandstone contained from a trace to $0.00 \mathrm{X}$ - percent of this element. Similarly, ytterbium occurs chiefly in mudstone which contains as much as $0.00 \mathrm{X}$ - of this element. Most of the samples of the mudstone in which ytterbium was detected, however, contained $0.000 \mathrm{X}$ - percent.

The gallium content of mudstone ranges from a trace (about $0.000 \mathrm{X}+$ percent) to $0.00 \mathrm{X}$ - percent, but most samples of sandstone contain less than trace amounts of gallium. The basal sandstone of the Salt Wash member, cored in hole 53, contained traces of gallium throughout its thickness. Very fine grained and silty sandstones generally contain traces of gallium in other holes studied.

Scandium, like gallium, is detectable only in mudstone and occurs in concentrations that range from a trace (about $0.000 \mathrm{X}+$ percent) to $0.00 \mathrm{X}$ - percent. Concentrations of scandium in sandstone are below the threshold of detection of the semiquantitative spectrographic method.

Only trace amounts of lanthanum are found in the mudstone of the Salt Wash member in the Jo Dandy area. If sandstone contains lanthanum the concentrations of this element are below the threshold of detection by the spectrographic method. Seven samples of green mudstone contained traces of lanthanum; five of these samples were collected from strata at the base of the ore-bearing sandstone lens or in a mudstone split within the ore-bearing sandstone. Three samples of red mudstone contained trace amounts of lanthanum. Two of the three samples were collected from strata overlying the orebearing sandstone (sample 28 in hole 71 and sample 18 in hole 64; section $B-B^{\prime}$ ) and one sample was taken from the mudstone overlying the basal sandstone layer of the Salt Wash member (sample 55 in hole 86).

\section{NICKEL AND COBALT}

Concentrations of nickel in mudstone range from $0.000 \mathrm{X}+$ to $0.00 \mathrm{X}$ - percent, a very narrow spread of values. Concentrations of nickel in sandstone range from less than trace amounts (about 
$0.000 \mathrm{X}-$ percent) to $0.000 \mathrm{X}+$ percent. Concentrations of cobalt in mudstone range from trace amounts (about $0.000 \mathrm{X}$ - percent) to $0.00 \mathrm{X}$ - percent, whereas concentrations in sandstone range from less than trace amounts to $0.000 \mathrm{X}+$ percent. Both elements are concentrated in mudstone strata and in thin sandstone lenses enclosed by mudstone (holes 62 and 95 ). A thick sandstone stratum containing mineralized material in hole 62 contains somewhat more nickel and cobalt than correlative units in holes 78 and 85 (fig. 21). But except for this occurrence, the sample data show no consistent relationship between the distribution of cobalt and nickel and the distribution of known ore bodies. Cobalt and nickel in host rocks of the Salt Wash member appear to be geochemically similar because the concentrations of one element show an excellent positive correlation with the concentrations of the other.

\section{COPPER}

The copper content of mudstone ranges from $0.00 \mathrm{X}-$ to $0.00 \mathrm{X}+$ percent; in sandstone the copper content ranges from $0.000 \mathrm{X}$ to $0.00 \mathrm{X}$ percent. The variation in concentrations of copper within correlative units of similar lithology are small. The distribution of copper shows no relationship to the distribution of known ore deposits. There is a tendency for copper to be distributed in a manner similar to that of vanadium, but the two elements do not appear to be distinctly related geochemically.

\section{LEAD, MOLYBDENUM, AND SILVER}

Lead is unquestionably concentrated in mudstone strata of the Salt Wash member of the Morrison formation in the Jo Dandy area. Concentrations range from less than trace amounts (about $0.000 \mathrm{X}+$ percent) to $0.00 \mathrm{X}+$ percent. Most samples of sandstone do not contain sufficient quantities of lead to be detectable by the analyticaI method used, but thin sandstone lenses below the base of the orebearing sandstone consistently contain detectable quantities of lead. The lead content of these thin sandstone lenses are represented by samples 11-13 in hole 62, by samples 89 and 90 in hole 95, and by sample 37 in hole 71.

Rocks of the Salt Wash member in the Jo Dandy area generally contain only traces or less of molybdenum and silver. However, two samples in hole 85 (samples 48 and 51) and one sample in hole 86 (sample 65) contained as much as $0.00 \mathrm{X}$ - percent molybdenum. The highest concentration of molybdenum (0.0X- percent) was found in a sample of black mudstone underlying the basal sandstone stratum of the Salt Wash member in drill hole 53 (sample 46). This 
black mudstone was probably derived by weathering in situ of the gypsum and black shale of the Paradox member of the Hermosa formation prior to deposition of the Morrison formation. This particular sample, in addition to containing molybdenum, also contains appreciable amounts of vanadium, copper, lead, boron, gallium, chromium, and a trace of silver. This sample was not included in calculations for the average composition of mudstone of the Salt Wash member. In addition to this one mudstone sample, trace amounts (about 0.00005 percent) of silver was reported in sample 11 , hole 62 .

\section{BISMUTH}

Bismuth is seldom found in sedimentary rocks of the Colorado Plateau in amounts exceeding the spectrographic threshold for that element (about $0.000 \mathrm{X}+$ percent). In the Jo Dandy area, however, bismuth was found in detectable quantities in 6 samples of drill core (samples 3, 5, and 6 in drill hole 62, and samples 17, 23, and 27 in drill hole 64). The quantities of bismuth in these core samples range from a trace (about $0.000 \mathrm{X}+$ percent) to $0.00 \mathrm{X}$ percent. Bismuth was also detected in both samples of gypsiferous material of the Paradox member of the Hermosa formation (samples 1 and 2) and from a large crystal of selenite collected from a fracture in the Mineral Joe mine (sample 67). Quantities of bismuth in gypsum range from $0.00 \mathrm{X}$ - to $0.00 \mathrm{X}+$ percent.

\section{EQUIVALENT URANIUM}

The radioactivity of unmineralized host rocks of the Salt Wash member in the Jo Dandy area varies with lithology; the samples of mudstone and fine-grained rocks are more radioactive than the samples of sandstone. Mudstone contains from 0.002 percent to 0.007 percent $\mathrm{eU}$, and mudstone (commonly green) directly adjacent to sandstone lenses are more radioactive than mudstone some distance above or below sandstone lenses. Values of eU in sandstone range from less than 0.001 to 0.003 percent; but only one sample of sandstone contained more than 0.002 percent.

\section{AVERAGE CHEMICAL COMPOSITION OF HOST ROCKS}

Geometric means representing the average chemical composition of host rocks were calculated for each of the following rock types: red and green mudstone and oxidized and unoxidized sandstone. The average chemical compositions of green and red mudstone and of oxidized and unoxidized sandstone are shown in table 2.

Geometric means given in this report should not be compared directly with published estimates of element abundance which are 


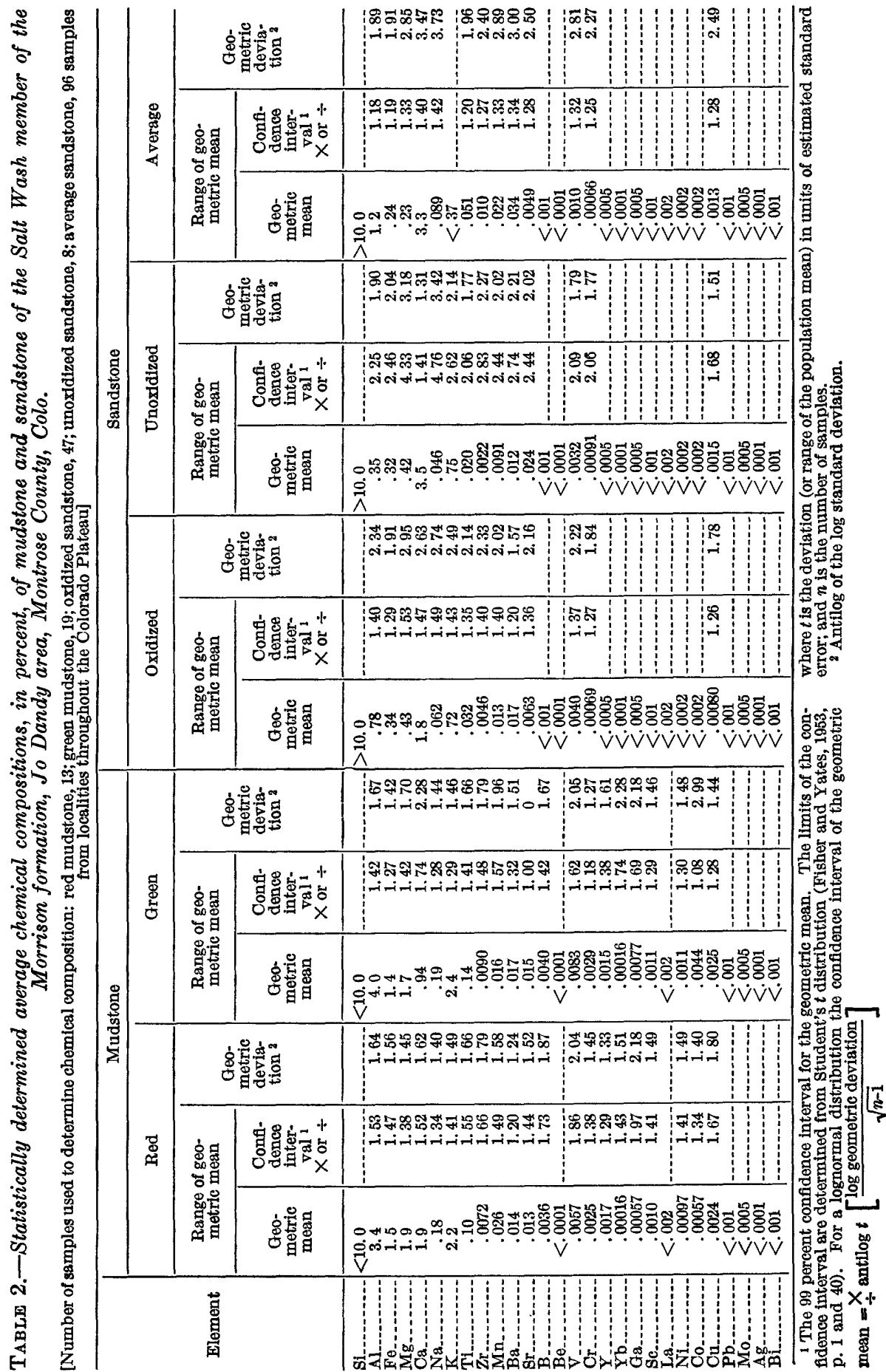


reported as arithmetic means. The geometric means for all the elements reported are invariably less than the estimated true arithmetic mean by an amount that is a function of the log standard deviation.

The composition of green mudstone differs only slightly, and probably not significantly, from the composition of red mudstone. In fact, a comparison of the two color varieties of mudstone shows a remarkable similarity in composition. The concentration of calcium alone may indicate a significant difference between red and green mudstone, as red mudstone appears to contain about twice as much calcium as does the green mudstone. However, there is no chemical evidence apparent in the data to establish a spatial relationship between the color of mudstone and mineralized sandstone.

The concentration of many elements depends on the mineral composition of the rock which in turn depends considerably upon the grain size of the rock. This is brought out by a comparison of the average chemical composition of sandstone with that of mudstone (table 2) in the Jo Dandy area. Mudstone contains about 5 times more aluminum than sandstone, 3 to 4 times more potassium, titanium, and chromium, up to twice as much vanadium, and about 5 times as much nickel, cobalt, and lead. Mudstone, likewise, contains most of the gallium and most of the rare earths that are found in the Salt Wash member such as scandium, ytterbium, lanthanum, and yttrium. Boron and beryllium are also concentrated in the finer grained rocks.

Unoxidized sandstone samples from the Jo Dandy area contain more calcium, strontium, and copper, and somewhat less aluminum than oxidized sandstone samples, whereas the concentrations of the other elements shown are quite similar in both types of sandstone. Mudstone contains more copper and aluminum than sandstone (see table 2; Rankama and Sahama, 1950, p. 226). Thus sandstone that contains more mudstone should also contain more aluminum and copper. Unoxidized sandstone in the Jo Dandy area, however, although containing less aluminum contains more copper than oxidized sandstone. This suggests that during processes of oxidation some copper is removed from the rocks, and perhaps the aluminum content is increased.

Sandstones of the Salt Wash member in the Jo Dandy area show unmistakable differences in chemical composition when compared with the composition of "average" sandstone of the Salt Wash member (table 2). The composition of "average" sandstone is based 
on semiquantitative spectrographic analyses of 96 samples of sandstone from the Salt Wash member collected from outcrops at widely scattered localities on the Colorado Plateau.

Sandstone in the Jo Dandy area contains more potassium, magnesium, vanadium, and nickel, and less aluminum, manganese, barium, titanium, and zirconium than average sandstone. Unoxidized sandstone in the Jo Dandy area contains about the same amount of calcium as does average sandstone, but the low concentrations of calcium in oxidized sandstone may be the result of a process of solution and redistribution of calcium in areas containing uranium deposits. The oxidation of pyrite and marcasite in sandstone may result in the formation of ferric sulfate and sulfuric acid. In this acid environment some calcium carbonate may undergo solution and redistribution. Thus sulfide-bearing sandstone upon oxidation may become locally depleted in calicum.

The abundant gypsum of the unoxidized sandstone is in the form of intergranular flour, cement, and fracture fillings which have healed the rock. Much of this gypsum may have been derived from exposed evaporite of the Paradox member of the Hermosa formation and incorporated in sediments of the Salt Wash during sedimentation. Some of this gypsum may have formed as a result of the solution of calcium carbonate in the oxidized sandstone and precipitated as intergranular material as a result of combination of $\mathrm{Ca}++$ with $\mathrm{SO}_{4}--$ and water. Deformation of the area accompanied by fracturing may have permitted the movement of some gypsum into fractures. Small and generally nonpersistent fractures were probably filled with gypsum in this manner. However, the larger through-going fractures also may have received some gypsum directly from the Paradox member. Field observations show that a gypsiferous, sulfide-bearing sandstone, which contains only sparse amounts of carbonate changes upon oxidation to a limonitic, locally uncemented sandstone in which only traces of gypsum remain along partly open fractures and through which carbonate cement is erratically distributed.

The greater amounts of potassium and magnesium in sandstone of the Salt Wash member in the Jo Dandy area may be in part derived from the Paradox member. Chemical evidence suggests that bismuth was, in part, derived from the Paradox member; and it seems reasonable to infer that such elements as potassium and magnesium also were in part derived from the Paradox member. Bismuth is seldom, if ever, detected in sedimentary rocks of the Colorado 
Plateau. In fact, it has never been detected by spectrographic methods in over 400 samples of sandstone, mudstone, limestone, evaporite, or oil shale from various parts of the Colorado Plateau. Because the occurrence of bismuth in the Jo Dandy area is unique, this element may be considered to be a tracer that links together the materials in which it is found. Bismuth was found in detectable quantities in samples of gypsum from the Paradox member exposed in Paradox Valley (fig. 20), and was also detected in 6 samples of drill core taken from the Salt Wash member. Thus Bismuth appears to have been either carried upward by a migration of solutions from the salt plug underlying Paradox Valley, or carried in gypsiferous detritus that was incorporated with sand and clay during deposition of the Salt Wash member. The fact that bismuth was also detected in a crystal of selenite found in a fracture of the Mineral Joe mine suggests that bismuth is capable of being carried in a sulfate solution.

\section{SUMMARY}

The chemical composition of each rock type of the Salt Wash member of the Morrison formation in the Jo Dandy area is remarkably uniform. The chemical compostion of red mudstone cannot be distinguished from the chemical composition of green mudstone except for the concentration of calcium; red mudstone samples contain about twice as much calcium as green mudstone in the area studied. Oxidized sandstone contains somewhat more aluminum, manganese, and zirconium, and about half as much calcium, strontium, and copper, as unoxidized sandstone.

Sandstone of the Jo Dandy area contains less aluminum, barium, zirconium, and manganese, but more potassium, magnesium, vanadium, nickel, and cobalt than "average" sandstone of the Salt Wash. The unusual amount of bismuth in some samples of host rock in the Jo Dandy area, and the occurrence of bismuth in samples of gypsum suggest that bismuth and probably some potassium and magnesium in rocks of the Salt Wash member were derived from the Paradox member of the Hermosa formation.

The persistently high concentrations of vanadium in the host rocks of the Jo Dandy area as compared to the vanadium content of average sandstone of the Salt Wash member suggests that vanadium may be useful as a pathfinder element in geochemical prospecting. 


\section{LITHOLOGIC DESCRIPTION OF SAMPLES}

[Described by W. L. Newman and J. D. Vogel]

\begin{tabular}{c|c}
\hline Sample & Outcrop samples \\
\hline 1 & $\begin{array}{c}\text { Lithology } \\
\text { Rock gypsum of Paradox member of the Hermosa formation; } \\
\text { cream to white, pulverulent; collected from bulldozer cut on west } \\
\text { side of landslide area. } \\
\text { Rock gypsum of Paradox member of the Hermosa formation; gray, } \\
\text { massive to platy, contorted; collected from outcrop along Colo- } \\
\text { rado Highway 90, 3 miles west of intersection with Monogram } \\
\text { truck trail. } \\
\text { Selenite crystal, 2 inches long and half an inch across; collected } \\
\text { from fracture in the Mineral Joe mine. }\end{array}$ \\
\hline
\end{tabular}

Drill-core samples from the Salt Wash member

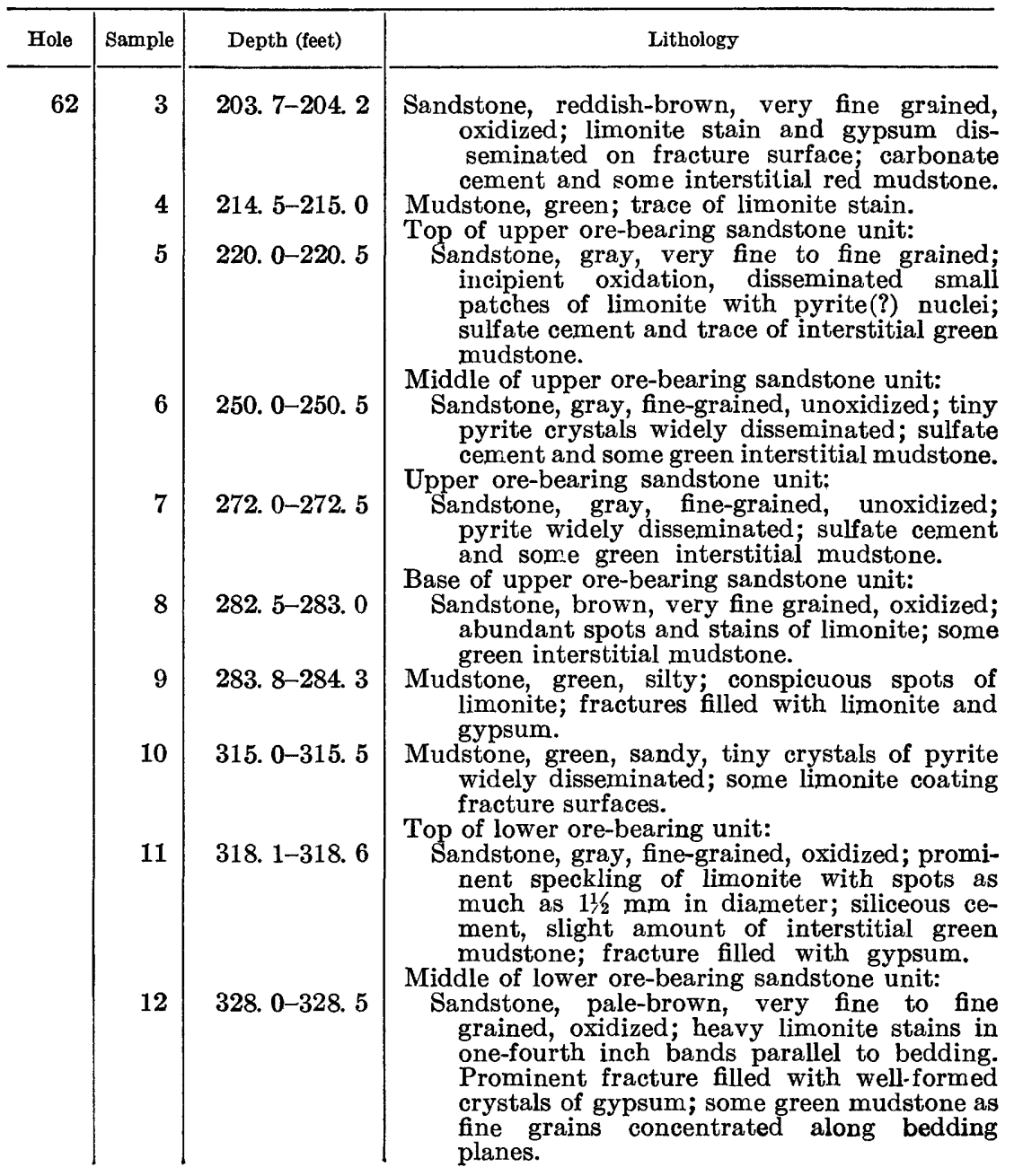


Drill-core samples from the Salt Wash member-Continued

\begin{tabular}{|c|c|c|}
\hline Hole & Sample & Depth (feet) \\
\hline \multirow[t]{2}{*}{62} & 13 & 334. 5-335. 0 \\
\hline & $\begin{array}{l}14 \\
15\end{array}$ & $\begin{array}{l}340.0-340.5 \\
358.0-358.5\end{array}$ \\
\hline \multirow[t]{10}{*}{64} & 16 & $54.6-55.1$ \\
\hline & 17 & $62.1-62.6$ \\
\hline & 18 & $66.6-67.1$ \\
\hline & 19 & $72.1-72,6$ \\
\hline & 20 & $85.2-85.7$ \\
\hline & 21 & $100.0-100.5$ \\
\hline & 22 & 115. 0-115. 5 \\
\hline & 23 & 130. 0-130. 5 \\
\hline & 24 & 145. $0-145.5$ \\
\hline & 25 & 160. $0-160.5$ \\
\hline \multirow[t]{3}{*}{71} & $\begin{array}{l}26 \\
27 \\
28 \\
29\end{array}$ & $\begin{array}{r}167.1-167.6 \\
179.6-180.1 \\
66.7-67.2 \\
72.7-73.2\end{array}$ \\
\hline & 30 & $74.2-74.7$ \\
\hline & 31 & $95.0-95.5$ \\
\hline
\end{tabular}

Base of lower ore-bearing sandstone unit:

Sandstone, brown, fine-grained, oxidized; abundant limonite spotting and staining; slightly cemented by carbonate; some flakes, pellets, and seams of yellowish-green mudstone.

Mudstone, green; traces of limonite.

Mudstone, reddish-brown; trace of manganese stain.

Mudstone, reddish-brown, silty, slightly calcareous.

Top of ore-bearing sandstone unit:

Sandstone, reddish-brown to light-brown, red cast due to red siltstone, very fine to fine grained, oxidized, slightly calcareous.

Mudstone, reddish-brown mottled with green, silty.

Ore-bearing sandstone unit:

Sandstone, pale-red, very fine and fine grained oxidized, friable; limonite as interstitial paint; trace of interstitial green mudstone; some white altered chert(?).

Sandstone, brown, fine-grained, oxidized; some limonite spotting and staining; sulfate cement and trace of interstitial green mudstone; abundant white altered chert(?).

Sandstone, pale-brown, fine-grained, oxidized; traces of limonite paint; thin films of green mudstone along bedding surfaces; abundant white altered chert(?).

Sandstone, brown, fine-grained, oxidized; limonite spotting and staining; sulfate cement, abundant interstitial grains and pellets of green mudstone; abundant white altered chert(?).

Sandstone, pale-brown, medium-grained, oxidized, friable; conspicuous limonite spotting; abundant white altered chert(?).

Sandstone, brown, fine- to medium-grained, friable, oxidized; abundant limonite as interstitial paint and stain; trace of yellowishbrown mudstone.

Sandstone, pale-brown, fine-grained, oxidized friable; trace of limonite paint; seams, films, and interstitial blebs of green mudstone; abundant white altered chert(?).

Mudstone, green, silty.

Mudstone, reddish-brown, silty.

Mudstone, reddish-brown.

Mudstone, grayish-green, very silty; some limonite stain.

Top of upper ore-bearing sandstone unit:

Sandstone, brown, fine-grained, oxidized; abundant spots of limonite; sulfate cement and sparse interstitial green mudstone; fracture filled with gypsum.

Middle of upper ore-bearing sandstone unit:

Sandstone, brown, fine-grained, oxidized; some spots of limonite; sulfate cement and some interstitial green mudstone; abundant white altered chert(?). 
DISTRIBUTION OF CHEMICAL ELEMENTS, SALT WASH MEMBER 141

Drill-core samples from the Salt Wash member-Continued

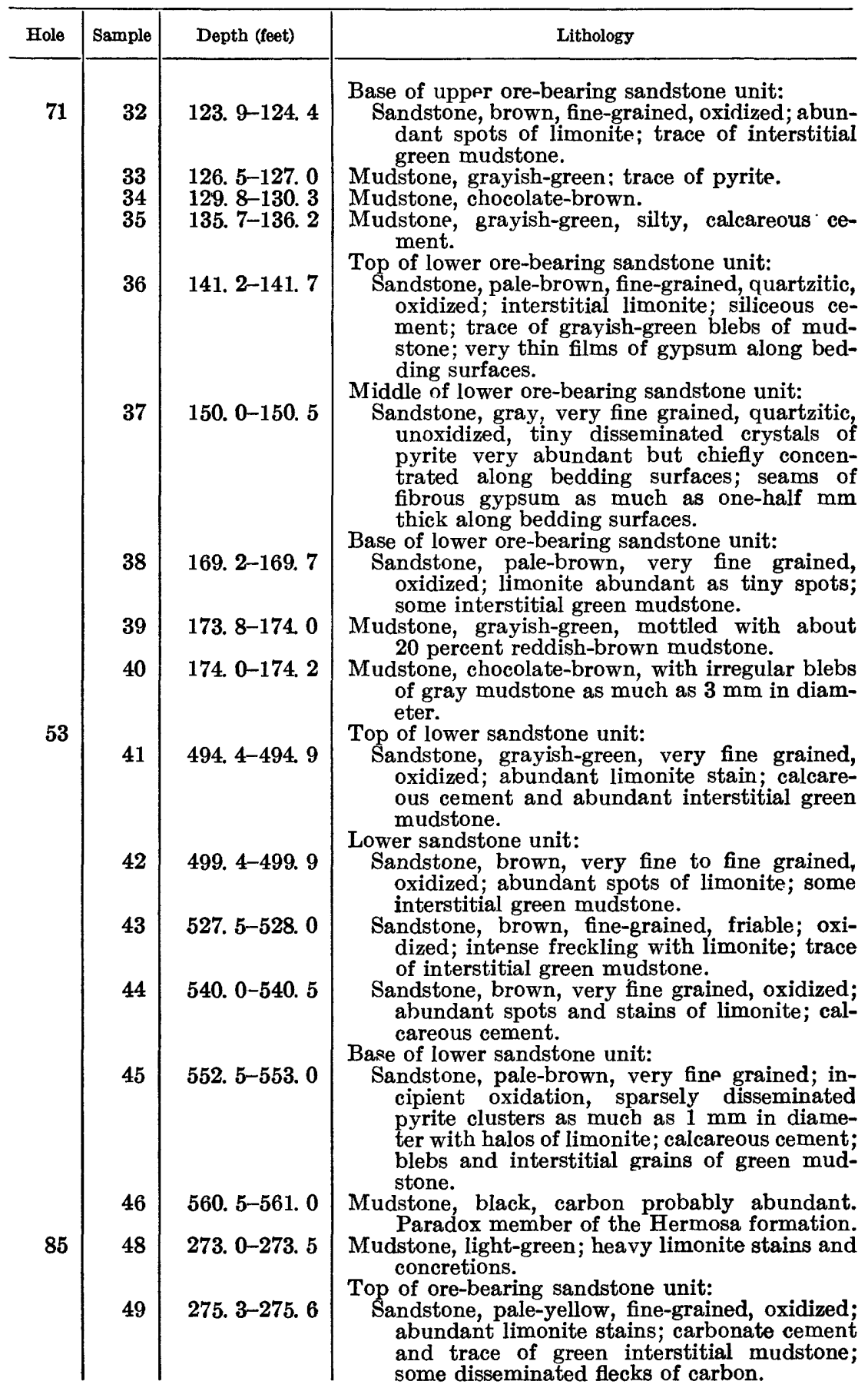


Drill-core samples from the Salt Wash member-Continued

\begin{tabular}{|c|c|c|c|}
\hline Hole & Sample & Depth (feet) & Lithology \\
\hline 85 & 50 & 315. 3-315. 6 & $\begin{array}{l}\text { Ore-bearing sandstone unit: } \\
\text { Sandstone, pale-brown, fine-grained, oxidized; } \\
\text { slight freckling with limonite; carbonate } \\
\text { cement; some white altered chert(?). } \\
\text { Middle of ore-bearing sandstone unit: } \\
\text { Sandstone, brown, fine-grained, oxidized; some }\end{array}$ \\
\hline
\end{tabular}

Sandstone, brown, fine-grained, oxidized; some spots and stains of limonite; carbonate cement; fractures filled with calcite.

Base of ore-bearing sandstone unit:

333. 1-333. 4

53

337. 6-337. 9

339. 9-340. 2

270. 2-270. 7

273. 4-273. 9

374. 7-375. 2

292. 7-293. 2

311. 9-312. 4

390. 8-391. 3

400. 8-401. 3

401. 8-402. 3

426. 7-427. 2

181. 1-181. 6

Sandstone, brown, fine-grained, oxidized; abundant spots and stains of limonite; carbonate cement; abundant flakes of green mudstone; abundant seams and films of carbon.

Mudstone, green.

Sandstone bed below ore-bearing sandstone unit:

Sandstone, pale-brown, very fine grained, oxidized; abundant spots of limonite; carbonate cement: some flakes of carbon; abundant fractures filled with gypsum; sparse films and interstitial grains of green mudstone.

Mudstone, reddish-brown; limonite and manganese stain on fracture surfaces.

Mudstone, grayish-green, very silty; some limonite stains.

Top of lower sandstone unit:

Sandstone, brown, fine-grained, oxidized; some spots of limonite: sulfate cement and abundant films and interstitial grains of green mudstone; some flakes of biotite; fractures filled with gypsum.

Mudstone, grayish-green, very silty.

Lower sandstone unit:

Sandstone, pale-brown, fine-grained, oxidized; faint speckling with limonite; carbonate cement and trace of interstitial green mudstone; gypsum coating fracture surfaces.

Sandstone, light-gray, very fine grained, quartzitic; incipient oxidation, traces of pyrite with halos of limonite; siliceous cement; sparse blebs and pods of green mudstone.

Sandstone, gray, fine-grained, quartzitic, unoxidized(?); siliceous cement; several fractures filled with gypsum.

Sandstone, grayish-green, very fine grained; sulfate cement; fibrous gypsum within vertical fracture; very abundant films, seams, and blebs of green mudstone and interstitial green siltstone.

Sandstone, pale-brown to white, fine-grained, oxidized; faint freckling with limonite.

Base of lower sandstone unit:

Sandstone, pale-brown, fine-grained, oxidized; sparse limonite, friable; trace of interstitial green mudstone.

Mudstone, gray, silty; limonite as stains and small concretion.

Mudstone, reddish-brown, very silty; trace of pyrite; some gypsum.

Mudstone, reddish-brown.

Sandstone bed above the ore-bearing sandstone unit:

192. 1-192. 6 Sandstone, grayish-green, very fine grained, unoxidized(?); carbonate cement; abundant films of green mudstone; fracture filled with gypsum. 
Drill-core samples from the Salt Wash member-Continued

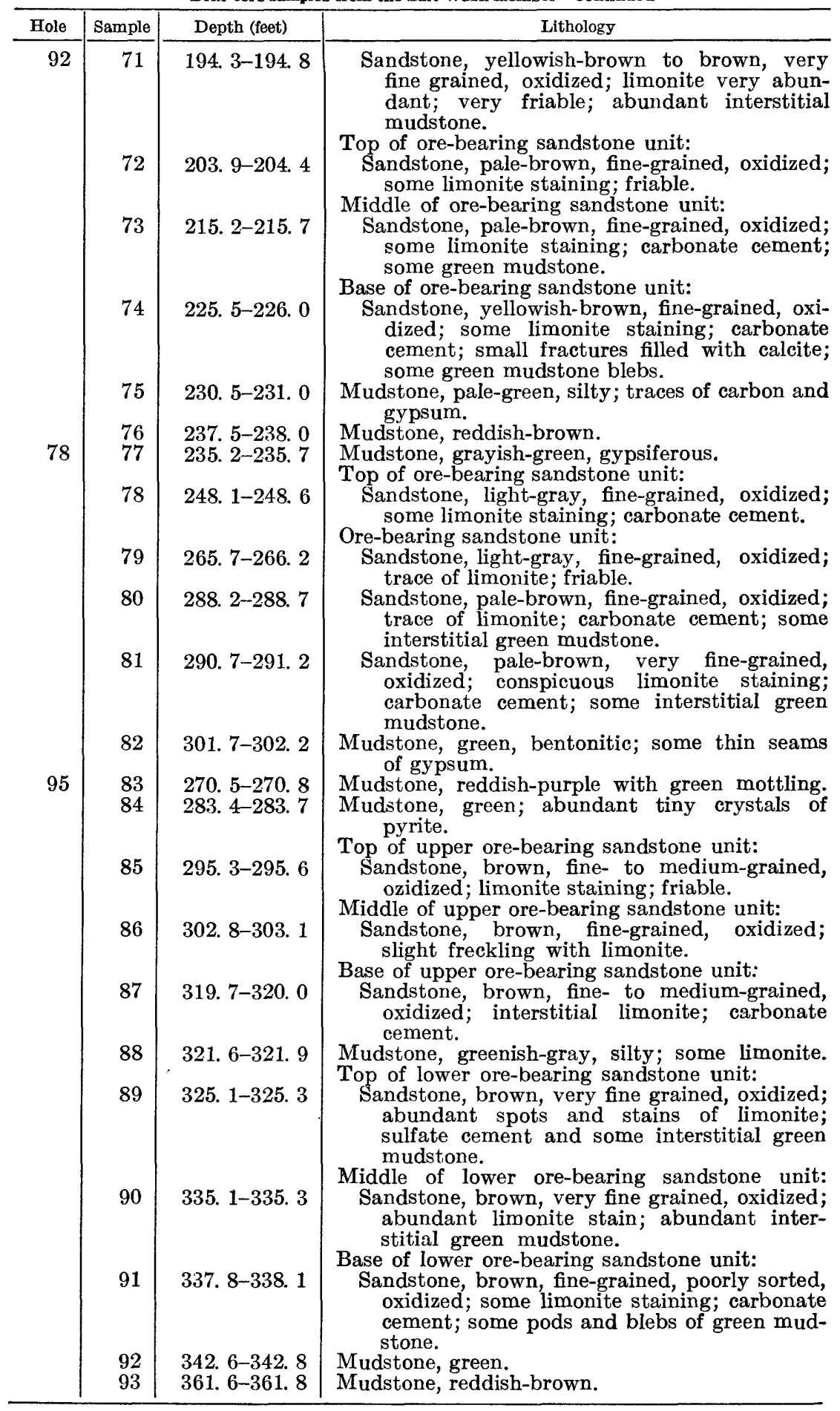




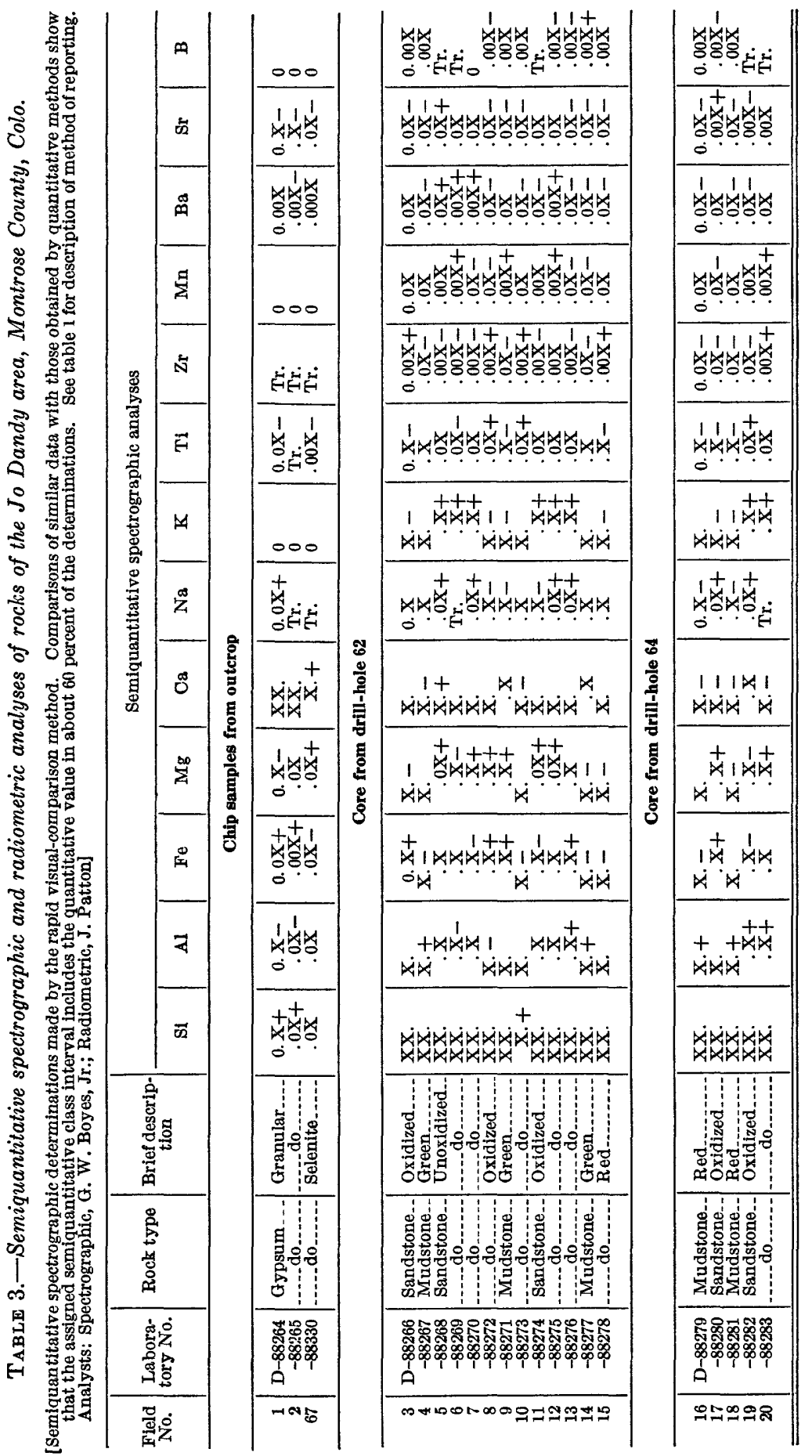


DISTRIBUTION OF CHEMICAL ELEMENTS, SALT WASH MEMBER 145

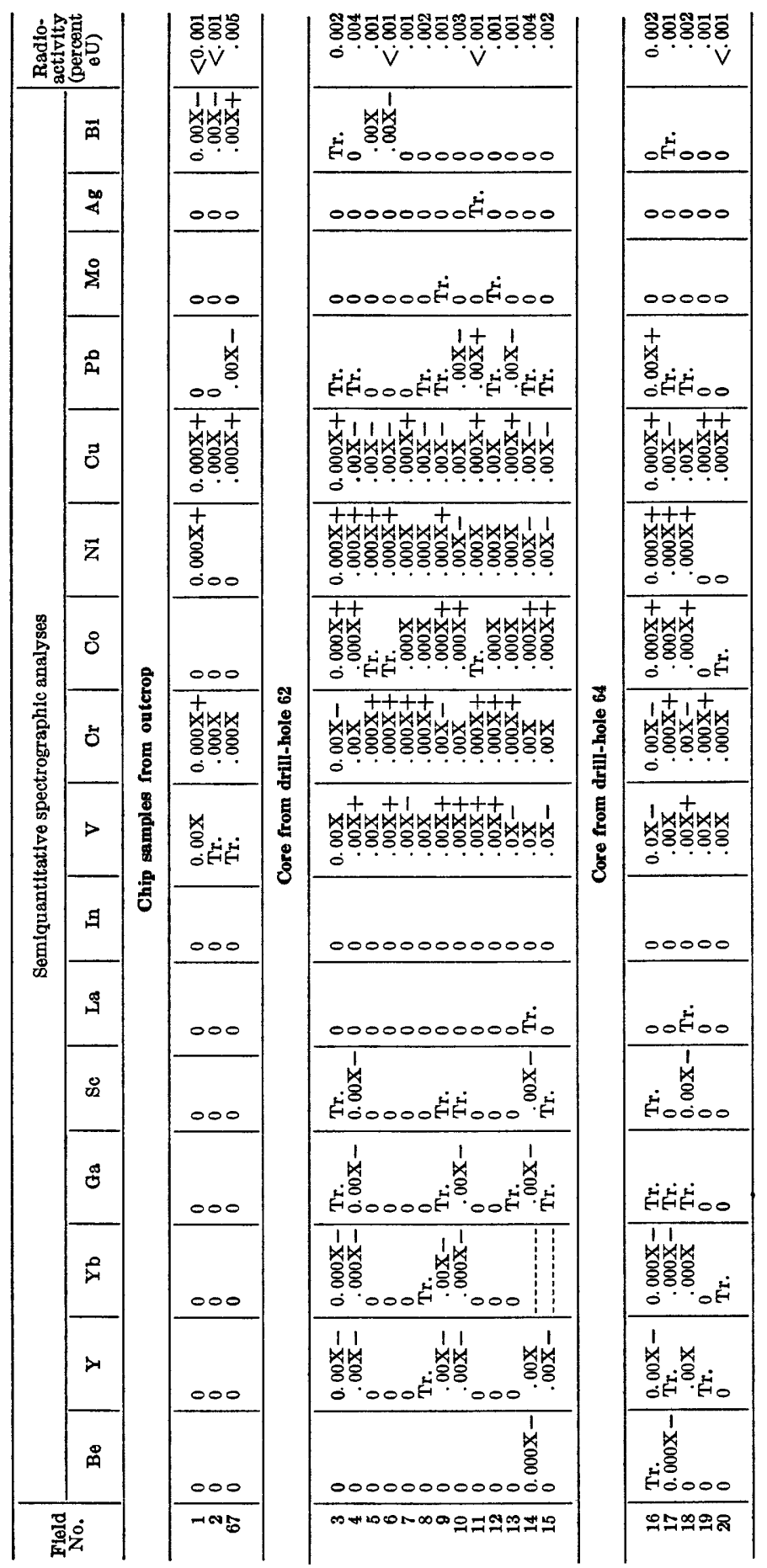




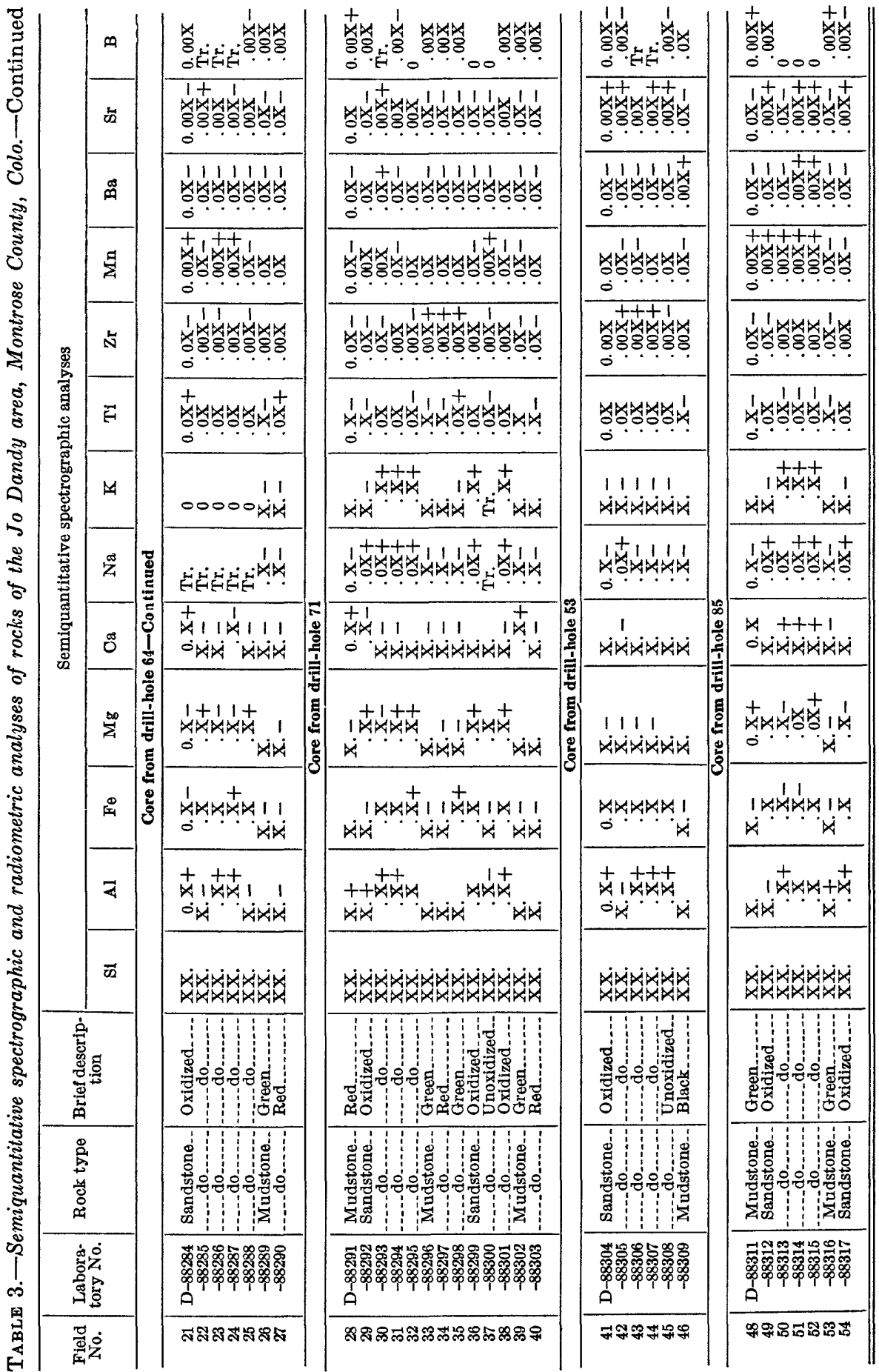


DISTRIBUTION OF CHEMICAL ELEMENTS, SALT WASH MEMBER 147

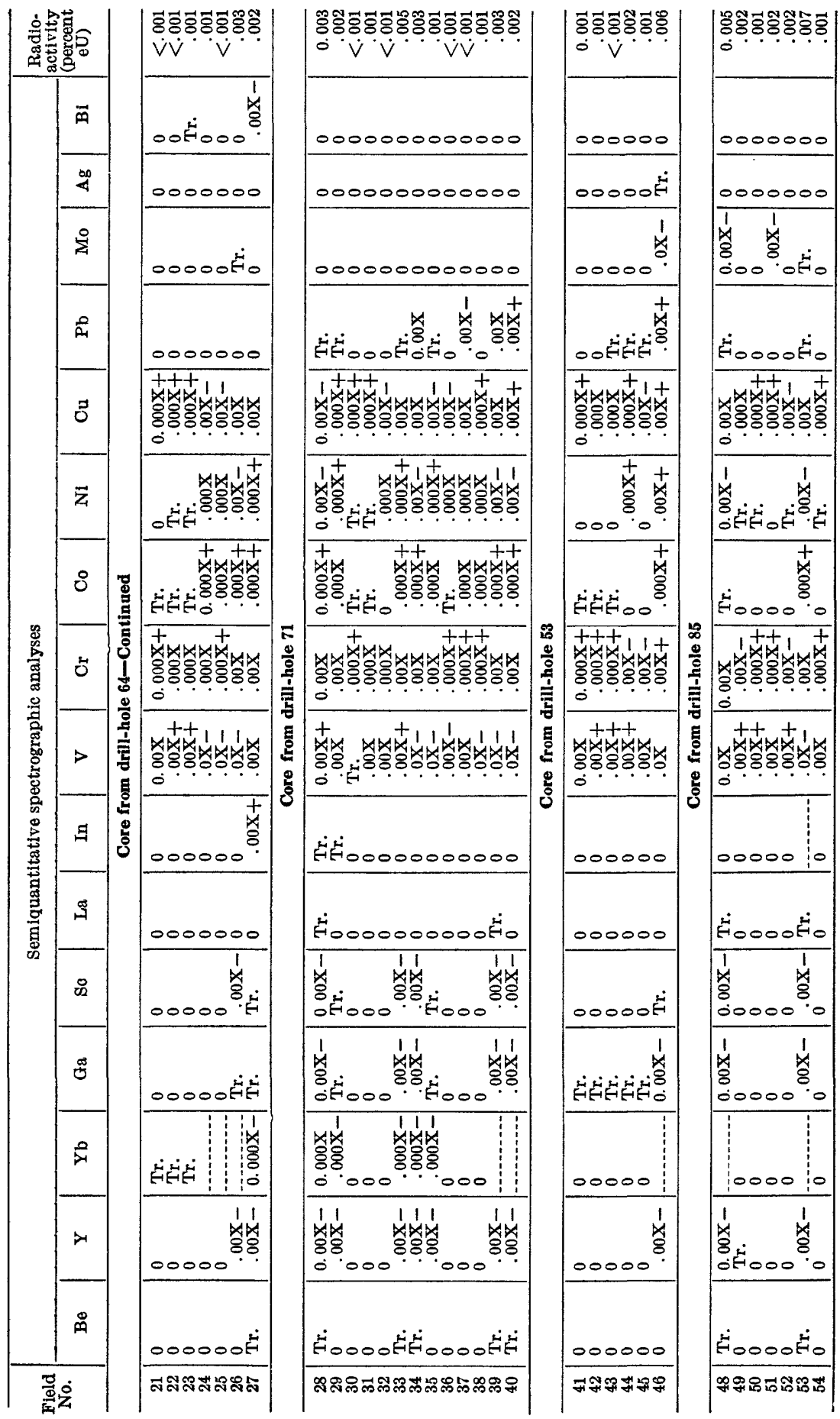



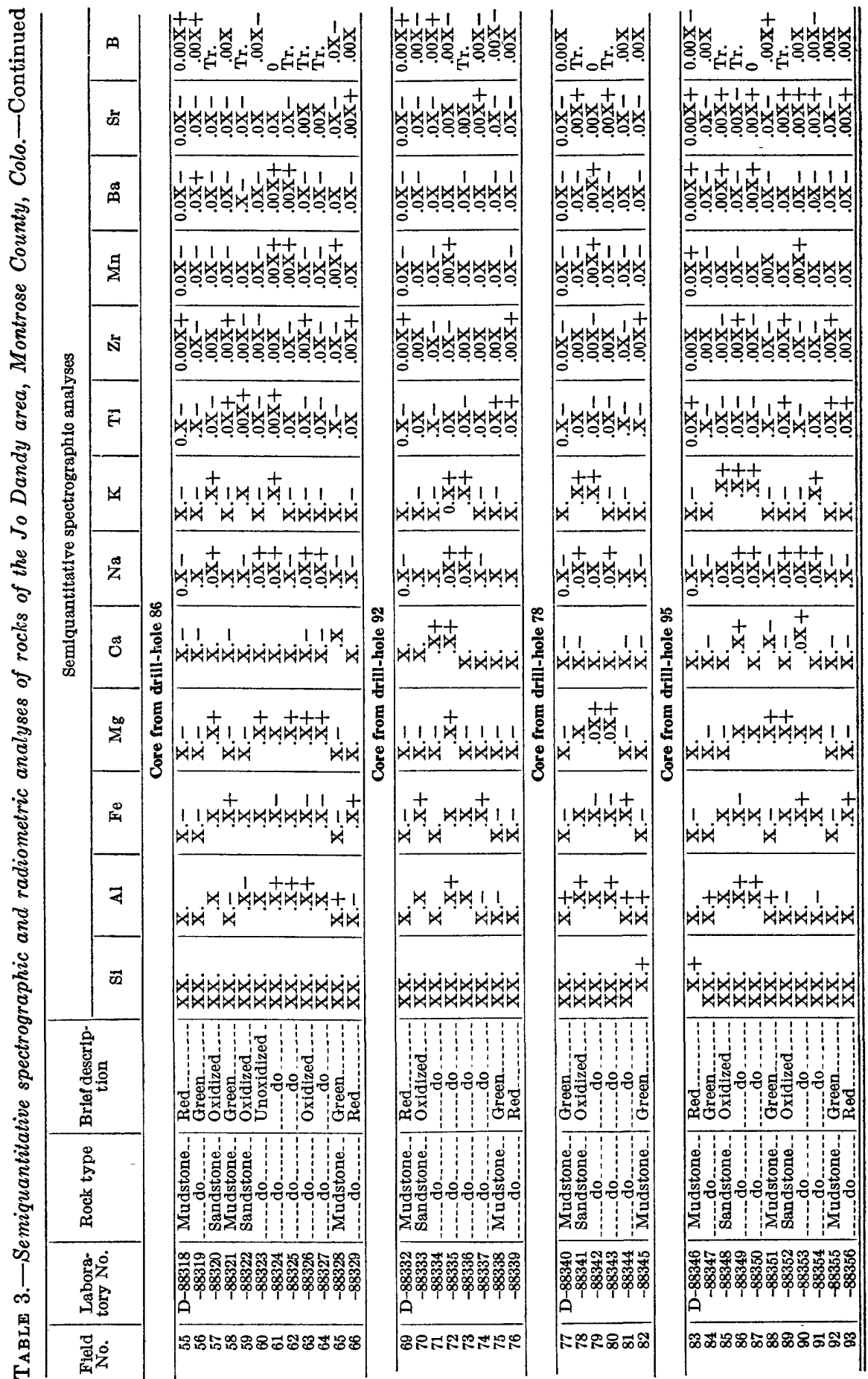
DISTRIBUTION OF CHEMICAL ELEMENTS, SALT WASH MEMBER 149

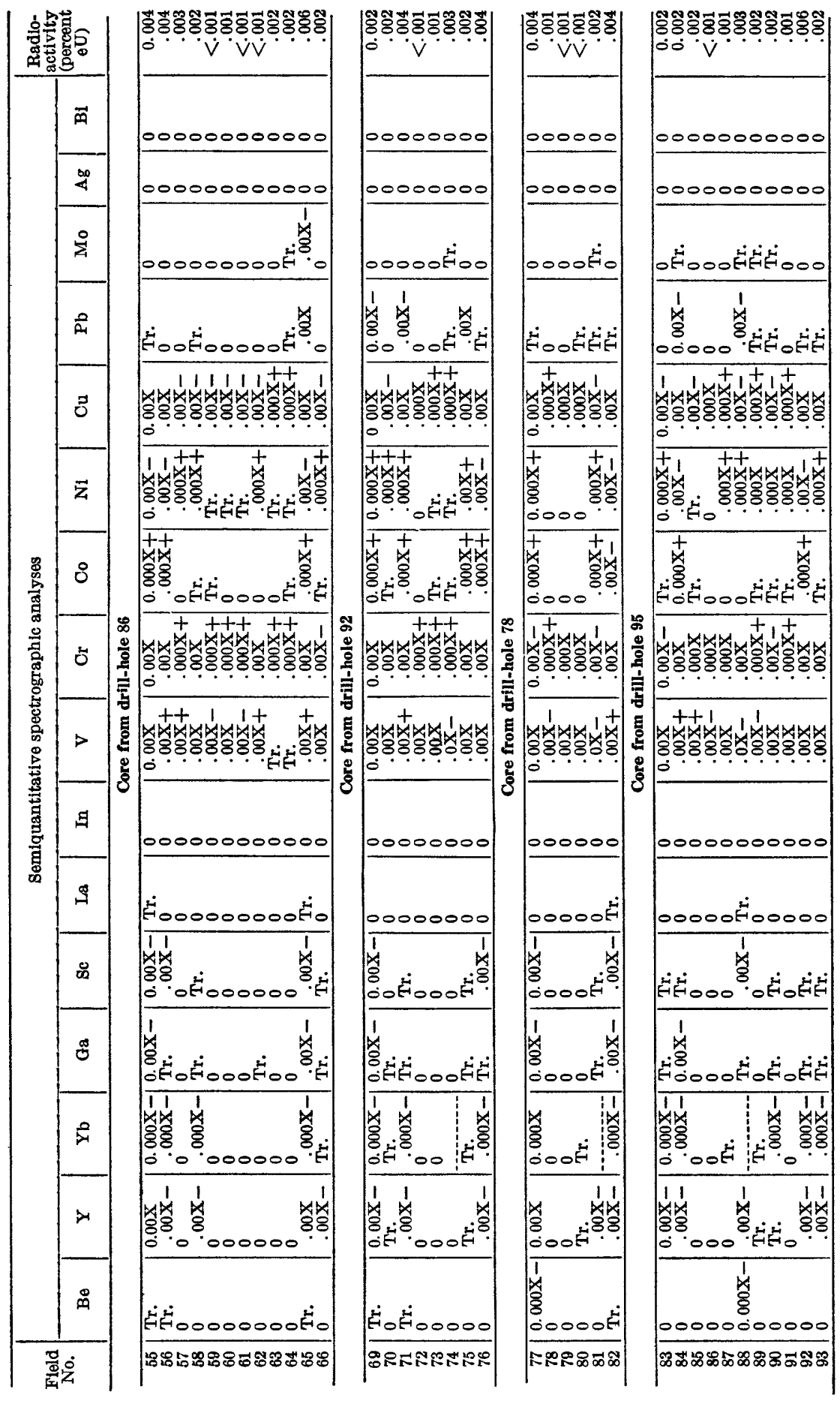




\section{REFERENCES CITED}

Ahrens, L. H., 1954, The lognormal distribution of the elements: Geochim. et Cosmochim. Acta, v. 5, p. 49-73.

Cater, F. W., Jr., 1955, Geology of the Naturita NW quadrangle, Colorado: U.S. Geol. Survey Geol. Quad. Map GQ 65.

Fisher, R. A., and Yates, Frank, 1953, Statistical tables for biological, agricultural, and medical research: New York, Hafner Pub. Co., p. 54.

McKay, E. J., 1955, Criteria for outlining areas favorable for uranium deposits in parts of Colorado and Utah: U.S. Geol. Survey Bull. 1009-J, p. 270-276.

McKee, E. D., and Weir, G. W., 1953, Terminology for stratification and crossstratification in sedimentary rocks: Geol. Soc. America Bull., v. 64, p. 381390.

Rankama, Kalervo, and Sahama, Th. G., 1950, Geochemistry: Chicago, Univ. of Chicago Press, p. 226.

Weeks, A. D., 1951, Red and gray clay underlying ore-bearing sandstone of the Morrison formation in western Colorado: U.S. Geol. Survey TEM-251, issued by U.S. Atomic Energy Comm. Tech. Inf. Service Ext., Oak Ridge, Tenn.

Weir, D. B., 1952, Geologic guides to prospecting for carnotite deposits on Colorado Plateau: U.S. Geol. Survey Bull. 988-B, p. 20. 

